\title{
Cleanup Verification Package for the 300-18 Waste Site
}

\author{
Prepared for the U.S. Department of Energy \\ by Bechtel Hanford, Inc.
}




\section{EXECUTIVE SUMMARY}

This cleanup verification package documents completion of remedial action for the 300-18 waste site. The 300-18 site is located within the 300-FF-2 Operable Unit in the 300 Area of the Hanford Site in southeastern Washington State. The site was identified in 1993 as an approximately $4.6-$ by $6.1-\mathrm{m}$ (15- by 20-ft) area containing radiologically contaminated soil, metal shavings, nuts and bolts, and concrete. The area was subsequently covered with 0.45 to $0.6 \mathrm{~m}(1.5 \mathrm{to} 2 \mathrm{ft})$ of soil for surface stabilization.

Site excavation and waste disposal are complete, and the exposed surfaces have been sampled and analyzed to verify attainment of the remedial action goals. Results of the sampling, laboratory analyses, and data evaluations for the 300-18 site indicate that all remedial action objectives and goals for direct exposure, protection of groundwater, and protection of the Columbia River have been met for industrial land use (Table ES-1).

Because residual soil concentrations indicated that cleanup levels for more stringent land uses may have been achieved for the 300-18 site, a supplemental evaluation was performed against unrestricted land-use cleanup objectives established in the Explanation of Significant Differences for the 300-FF-2 Operable Unit Record of Decision (EPA 2004). Results of the evaluation (Table ES-2) demonstrate that residual contaminant concentrations do not preclude any future uses (as bounded by the rural-residential scenario) and allow for unrestricted use of shallow zone soils (i.e., surface to $4.6 \mathrm{~m}$ [15 ft] deep). This site does not have a deep zone; therefore, no deep zone institutional controls are required.

The site meets cleanup standards and has been reclassified as "interim closed out" in accordance with the Hanford Federal Facility Agreement and Consent Order (Ecology et al. 1989) and the Waste Site Reclassification Guideline TPA-MP-14 (RL-TPA-90-0001) (DOE-RL 1998). A copy of the waste site reclassification form is included as Attachment ES-1. 


\section{Table ES-1. Summary of Cleanup Verification Results for the 300-18 Waste Site - Industrial Land Use.}

\begin{tabular}{|c|c|c|c|}
\hline $\begin{array}{l}\text { Regulatory } \\
\text { Requirement }\end{array}$ & Remedial Action Goals & Results & $\begin{array}{l}\text { Remedial } \\
\text { Action } \\
\text { Objectives } \\
\text { Attained? }\end{array}$ \\
\hline $\begin{array}{l}\text { Direct Exposure - } \\
\text { Radionuclides }\end{array}$ & $\begin{array}{l}\text { Attain } 15 \mathrm{mrem} / \mathrm{yr} \text { dose rate above } \\
\text { background over } 1,000 \text { years. Attain } \\
\text { the CERCLA risk range of } 10^{-4} \text { to } \\
10^{-6} \text {. }\end{array}$ & $\begin{array}{l}\text { No radionuclide COCs were detected } \\
\text { above background levels. }\end{array}$ & Yes \\
\hline $\begin{array}{l}\text { Direct Exposure - } \\
\text { Nonradionuclides }\end{array}$ & Attain individual COC RAGs. & $\begin{array}{l}\text { All individual COC concentrations are } \\
\text { below the RAGs. }\end{array}$ & Yes \\
\hline \multirow{4}{*}{$\begin{array}{l}\text { Meet } \\
\text { Nonradionuclide Risk } \\
\text { Requirements }\end{array}$} & $\begin{array}{l}\text { Hazard quotient of }<1 \text { for } \\
\text { noncarcinogens. }\end{array}$ & \multirow{2}{*}{$\begin{array}{l}\text { Hazard quotients were not calculated } \\
\text { because all nonradionuclide COCs } \\
\text { (arsenic, barium, beryllium, cadmium, } \\
\text { chromium, and lead) were detected } \\
\text { below statistical background levels. }\end{array}$} & \multirow{4}{*}{ Yes } \\
\hline & $\begin{array}{l}\text { Cumulative hazard quotient of }<1 \text { for } \\
\text { noncarcinogens. }\end{array}$ & & \\
\hline & $\begin{array}{l}\text { Excess cancer risk of }<1 \times 10^{-6} \text { for } \\
\text { individual carcinogens. }\end{array}$ & \multirow{2}{*}{$\begin{array}{l}\text { Excess cancer risks were not } \\
\text { calculated because all nonradionuclide } \\
\text { carcinogenic COCs (arsenic, beryllium, } \\
\text { and cadmium) were detected below } \\
\text { statistical background levels. }\end{array}$} & \\
\hline & $\begin{array}{l}\text { Attain a total excess cancer risk of } \\
<1 \times 10^{-5} \text { for carcinogens. }\end{array}$ & & \\
\hline \multirow{4}{*}{$\begin{array}{l}\text { Groundwater/River } \\
\text { Protection - } \\
\text { Radionuclides }\end{array}$} & $\begin{array}{l}\text { Attain single-COC groundwater and } \\
\text { river protection RAGs. }\end{array}$ & $\begin{array}{l}\text { All single-COC groundwater and river } \\
\text { RAGs have been attained. }\end{array}$ & \multirow{4}{*}{ Yes } \\
\hline & $\begin{array}{l}\text { Attain National Primary Drinking } \\
\text { Water Standards: } 4 \text { mrem/yr } \\
\text { (beta/gamma) dose rate to target } \\
\text { receptor/organs. }\end{array}$ & $\begin{array}{l}\text { No beta/gamma-emitting COCs were } \\
\text { identified for this site. }\end{array}$ & \\
\hline & $\begin{array}{l}\text { Meet drinking water standards for } \\
\text { nonuranium alpha emitters: the more } \\
\text { stringent of the } 15 \mathrm{pCi} / \mathrm{L} \mathrm{MCL} \\
\text { or } 1 / 25^{\text {th }} \text { of the derived concentration } \\
\text { guide per DOE Order } 5400.5 \text {. }\end{array}$ & $\begin{array}{l}\text { No beta/gamma-emitting COCs were } \\
\text { identified for this site. }\end{array}$ & \\
\hline & $\begin{array}{l}\text { Meet total uranium standard of } \\
21.2 \mathrm{pCi} / \mathrm{L}^{\mathrm{a}}\end{array}$ & $\begin{array}{l}\text { Uranium statistical values are below } \\
\text { background for this site. }\end{array}$ & \\
\hline $\begin{array}{l}\text { Groundwater/River } \\
\text { Protection - } \\
\text { Nonradionuclides }\end{array}$ & $\begin{array}{l}\text { Attain individual nonradionuclide } \\
\text { groundwater and river cleanup } \\
\text { requirements. }\end{array}$ & $\begin{array}{l}\text { All the groundwater and river RAGs } \\
\text { have been attained. }\end{array}$ & Yes \\
\hline $\begin{array}{l}\text { Supporting } \\
\text { Information }\end{array}$ & \multicolumn{3}{|c|}{$\begin{array}{l}\text { Cleanup verification } 95 \% \text { UCL Calculation (Appendix C). }{ }^{b} \\
\text { Cleanup verification sample location design (Appendix C). }{ }^{c}\end{array}$} \\
\hline \multicolumn{4}{|c|}{ 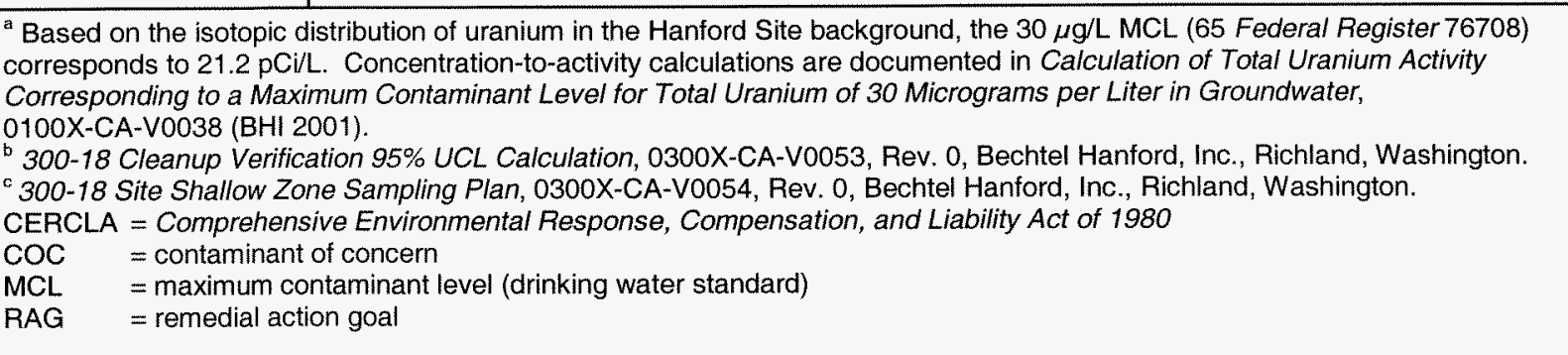 } \\
\hline
\end{tabular}




\section{Table ES-2. Summary of Cleanup Verification Results for the 300-18 Waste Site - Unrestricted Land Use.}

\begin{tabular}{|c|c|c|c|}
\hline $\begin{array}{l}\text { Regulatory } \\
\text { Requirement }\end{array}$ & Remedial Action Goals & Results & $\begin{array}{l}\text { Remedial } \\
\text { Action } \\
\text { Objectives } \\
\text { Attained? }\end{array}$ \\
\hline $\begin{array}{l}\text { Direct Exposure - } \\
\text { Radionuclides }\end{array}$ & $\begin{array}{l}\text { Attain } 15 \mathrm{mrem} / \mathrm{yr} \text { dose rate above } \\
\text { background over } 1,000 \text { years. Attain } \\
\text { the CERCLA risk range of } 10^{-4} \text { to } \\
10^{-6} \text {. }\end{array}$ & $\begin{array}{l}\text { No radionuclide COCs were detected } \\
\text { above background levels. }\end{array}$ & Yes \\
\hline $\begin{array}{l}\text { Direct Exposure - } \\
\text { Nonradionuclides }\end{array}$ & Attain individual COC RAGs. & $\begin{array}{l}\text { All individual COC concentrations are } \\
\text { below the RAGs. }\end{array}$ & Yes \\
\hline \multirow{4}{*}{\begin{tabular}{|l|} 
Meet \\
Nonradionuclide Risk \\
Requirements
\end{tabular}} & $\begin{array}{l}\text { Hazard quotient of }<1 \text { for } \\
\text { noncarcinogens. }\end{array}$ & \multirow{2}{*}{$\begin{array}{l}\text { Hazard quotients were not calculated } \\
\text { because all nonradionuclide COCs } \\
\text { (arsenic, barium, beryllium, cadmium, } \\
\text { chromium, and lead) were detected } \\
\text { below statistical background levels. }\end{array}$} & \multirow{4}{*}{ Yes } \\
\hline & $\begin{array}{l}\text { Cumulative hazard quotient of }<1 \text { for } \\
\text { noncarcinogens. }\end{array}$ & & \\
\hline & $\begin{array}{l}\text { Excess cancer risk of }<1 \times 10^{-6} \text { for } \\
\text { individual carcinogens. }\end{array}$ & \multirow{2}{*}{$\begin{array}{l}\text { Excess cancer risks were not } \\
\text { calculated because all nonradionuclide } \\
\text { carcinogenic COCs (arsenic, beryllium, } \\
\text { and cadmium) were detected below } \\
\text { statistical background levels. }\end{array}$} & \\
\hline & $\begin{array}{l}\text { Attain a total excess cancer risk of } \\
<1 \times 10^{-5} \text { for carcinogens. }\end{array}$ & & \\
\hline \multirow{4}{*}{$\begin{array}{l}\text { Groundwater/River } \\
\text { Protection - } \\
\text { Radionuclides }\end{array}$} & $\begin{array}{l}\text { Attain single-COC groundwater and } \\
\text { river protection RAGs. }\end{array}$ & $\begin{array}{l}\text { All single-COC groundwater and river } \\
\text { RAGs have been attained. }\end{array}$ & \multirow{4}{*}{ Yes } \\
\hline & $\begin{array}{l}\text { Attain National Primary Drinking } \\
\text { Water Standards: } 4 \text { mrem/yr } \\
\text { (beta/gamma) dose rate to target } \\
\text { receptor/organs. }\end{array}$ & $\begin{array}{l}\text { No beta/gamma-emitting COCs were } \\
\text { identified for this site. }\end{array}$ & \\
\hline & $\begin{array}{l}\text { Meet drinking water standards for } \\
\text { nonuranium alpha emitters: the more } \\
\text { stringent of the } 15 \mathrm{pCi} / \mathrm{L} \mathrm{MCL} \\
\text { or } 1 / 25^{\text {th }} \text { of the derived concentration } \\
\text { guide per DOE Order } 5400.5 \text {. }\end{array}$ & $\begin{array}{l}\text { No nonuranium alpha-emitting COCs } \\
\text { were identified for this site. }\end{array}$ & \\
\hline & $\begin{array}{l}\text { Meet total uranium standard of } \\
21.2 \mathrm{pCi} / \mathrm{L}^{\mathrm{a}}\end{array}$ & $\begin{array}{l}\text { Uranium statistical values are below } \\
\text { background for this site. }\end{array}$ & \\
\hline $\begin{array}{l}\text { Groundwater/River } \\
\text { Protection - } \\
\text { Nonradionuclides }\end{array}$ & $\begin{array}{l}\text { Attain individual nonradionuclide } \\
\text { groundwater and river cleanup } \\
\text { requirements. }\end{array}$ & $\begin{array}{l}\text { All the groundwater and river RAGs } \\
\text { have been attained. }\end{array}$ & Yes \\
\hline $\begin{array}{l}\text { Supporting } \\
\text { Information }\end{array}$ & \multicolumn{3}{|c|}{$\begin{array}{l}\text { Cleanup verification } 95 \% \text { UCL Calculation (Appendix C). }{ }^{b} \\
\text { Cleanup verification sample location design (Appendix C). }\end{array}$} \\
\hline \multicolumn{4}{|c|}{$\begin{array}{l}\text { "Based on the isotopic distribution of uranium in the Hanford Site b } \\
\text { corresponds to } 21.2 \mathrm{pCi} \text { L. Concentration-to-activity calculations a } \\
\text { Corresponding to a Maximum Contaminant Level for Total Uranium } \\
0100 \mathrm{X}-\mathrm{CA} \text {-V0038 (BHI 2001). } \\
300-18 \text { Cleanup Verification } 95 \% \text { UCL Calculation, 0300X-CA-Vo } \\
300-18 \text { Site Shallow Zone Sampling Plan, 0300X-CA-V0054, Rev. } \\
\text { CERCLA = Comprehensive Environmental Response, Compensat } \\
\text { COC = contaminant of concern } \\
\text { MCL = maximum contaminant level (drinking water standard) } \\
\text { RAG = remedial action goal }\end{array}$} \\
\hline
\end{tabular}


CVP-2005-00004

Rev. 0

ES-4 
CVP-2005-00004

Rev. 0

Attachment ES-1

Waste Site Reclassification Form

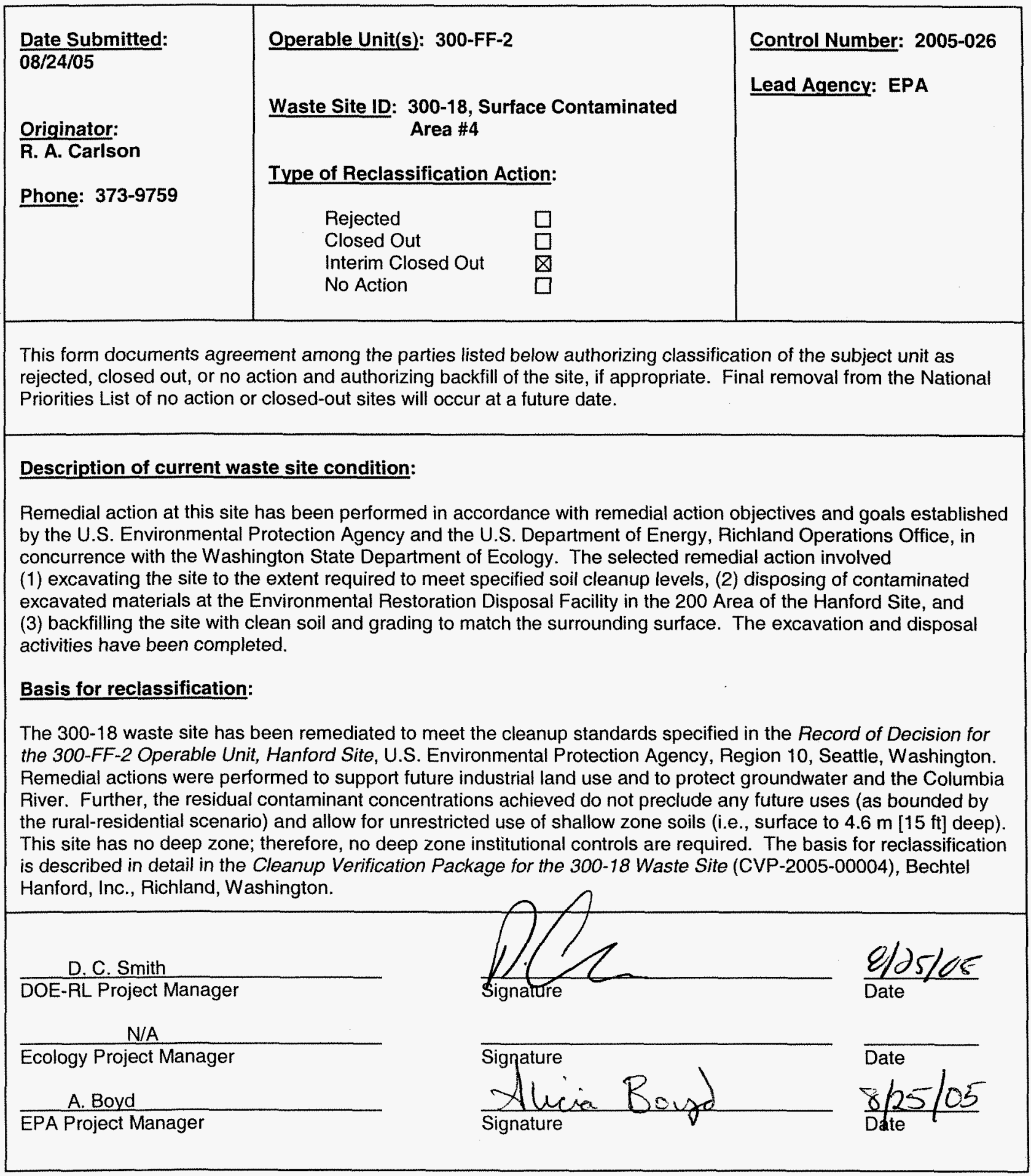


CVP-2005-00004

Rev. 0

ES-6 


\section{CONTENTS}

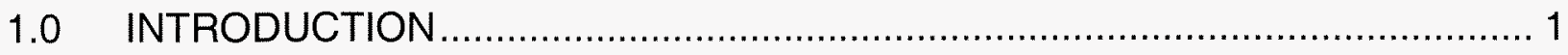

2.0 SITE DESCRIPTION AND SUPPORTING INFORMATION N........................... 1

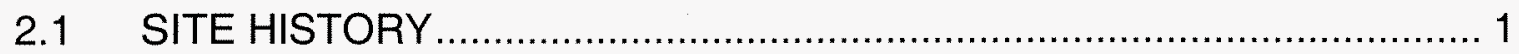

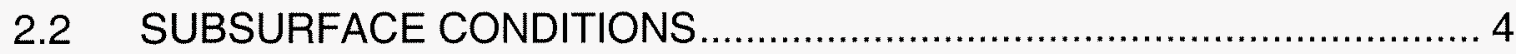

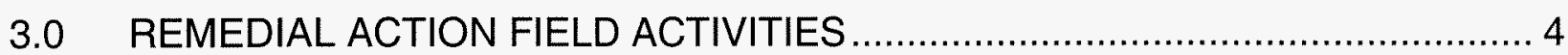

3.1 EXCAVATION AND DISPOSAL ........................................................ 4

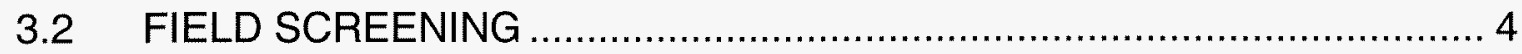

3.3 BIASED SAMPLING AND ANALYSIS ......................................... 8

3.4 CLEANUP VERIFICATION SAMPLING AND ANALYSIS ..................... 8

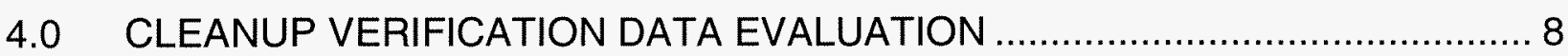

4.1 DATA QUALITY ASSESSMENT PROCESS .................................. 8

4.2 CONTAMINANTS OF CONCERN 95\% UPPER CONFIDENCE LIMIT ..... 9

4.3 SITE-SPECIFIC CLEANUP VERIFICATION MODEL …..................... 9

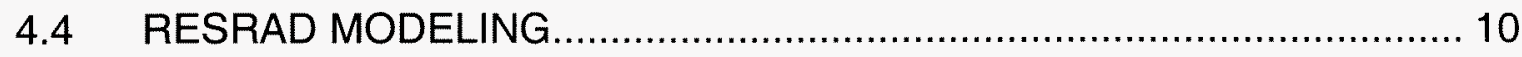

5.0 EVALUATION OF REMEDIAL ACTION GOAL ATTAINMENT

FOR INDUSTRIAL LAND USE.............................................................. 10

5.1 DIRECT EXPOSURE SOIL REMEDIAL ACTION GOALS ATTAINED ... 11

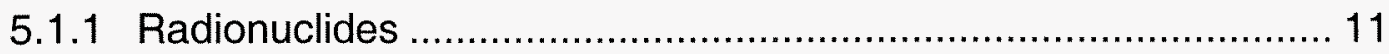

5.1.2 Nonradionuclides ................................................................. 11

5.2 GROUNDWATER REMEDIAL ACTION GOALS ATTAINED ................ 12

5.2.1 Radionuclides ................................................................... 12

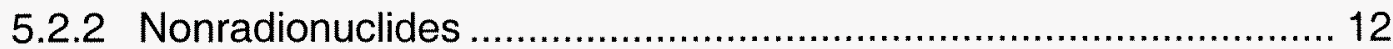

5.3 COLUMBIA RIVER REMEDIAL ACTION GOALS ATTAINED …........... 12

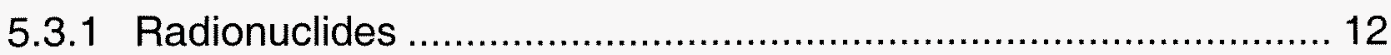

5.3.2 Nonradionuclides .............................................................. 12

5.4 WAC 173-340 THREE-PART TEST FOR NONRADIONUCLIDES ......... 13

6.0 EVALUATION OF REMEDIAL ACTION GOAL ATTAINMENT FOR UNRESTRICTED LAND USE ........................................................... 13

6.1 DIRECT EXPOSURE SOIL REMEDIAL ACTION GOALS ATTAINED .... 14

6.1.1 Radionuclides .................................................................. 14

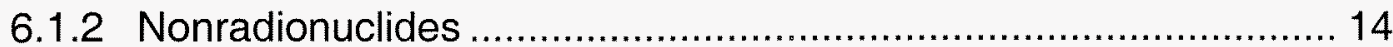

6.2 GROUNDWATER REMEDIAL ACTION GOALS ATTAINED ................ 15

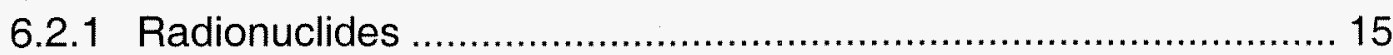

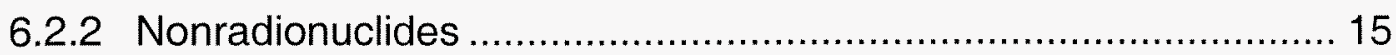

6.3 COLUMBIA RIVER REMEDIAL ACTION GOALS ATTAINED …........... 15

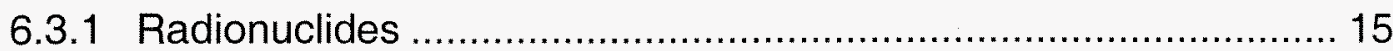

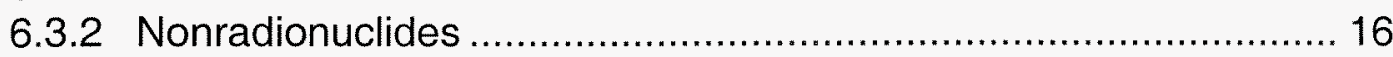

6.4 WAC 173-340 THREE-PART TEST FOR NONRADIONUCLIDES ......... 16 
7.0 STATEMENT OF PROTECTIVENESS ................................................... 16

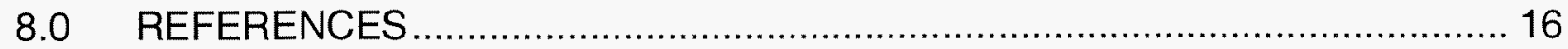

\section{APPENDICES}

A SUMMARY OF VERIFICATION SOIL SAMPLING AND ANALYTICAL

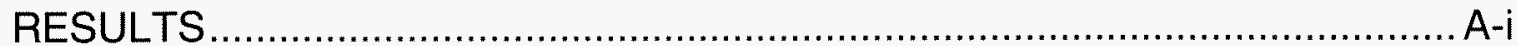

B DATA QUALITY ASSESSMENT FOR THE 300-18 WASTE SITE ................... B-i

C CALCULATION BRIEF EXCERPTS …..........................................................

C1 300-18 Site Shallow Zone Sampling Plan, 0300X-CA-V0054 ....................-3

C2 300-18 Cleanup Verification 95\% UCL Calculation, 0300X-CA-V0053 ........-9

\section{FIGURES}

1. Hanford Site Map and Location of the $300-18$ Site........................................... 3

2. Pre-Remediation Topographic Plan for the 300-18 Site.................................. 5

3. Post-Remediation Topographic Plan for the 300-18 Site. ................................. 6

4. Radiological Mapping Survey Results for the 300-18 Site................................. 7

\section{TABLES}

1. Summary of Remedial Action Goals - Industrial Land Use............................... 2

2. Cleanup Verification Data Set. ................................................................. 10

3. Attainment of Nonradionuclide Direct Exposure Standards Industrial Land Use.

4. Attainment of Nonradionuclide Direct Exposure Standards Unrestricted Land Use. 


\section{ACRONYMS AND ABBREVIATIONS}

$\begin{array}{ll}\text { COC } & \text { contaminant of concern } \\ \text { DQA } & \text { data quality assessment } \\ \text { ERDF } & \text { Environmental Restoration Disposal Facility } \\ \text { ESD } & \text { explanation of significant differences } \\ \text { RAG } & \text { remedial action goal } \\ \text { RAO } & \text { remedial action objective } \\ \text { RDR/RAWP } & \text { remedial design report/remedial action work plan } \\ \text { RESRAD } & \text { RESidual RADioactivity dose assessment model } \\ \text { ROD } & \text { record of decision } \\ \text { SAP } & \text { sampling and analysis plan } \\ \text { UCL } & \text { upper confidence limit } \\ \text { WAC } & \text { Washington Administrative Code }\end{array}$


CVP-2005-00004

Rev. 0 


\subsection{INTRODUCTION}

The purpose of this cleanup verification package is to document that the $300-18$ waste site was remediated in accordance with the Record of Decision for the 300-FF-2 Operable Unit, Hanford Site (ROD) (EPA 2001). Remedial action objectives (RAOs) and remedial action goals (RAGs) for the 300-18 site are documented in the ROD (EPA 2001) and the Remedial Design Report/Remedial Action Work Plan for the 300 Area (RDR/RAWP) (DOE-RL 2004b). The ROD provides the U.S. Department of Energy, Richland Operations Office the authority, guidance, and objectives to conduct this remedial action.

The preferred remedy specified in the ROD (EPA 2001) and conducted for the 300-18 site included (1) excavating the site to the extent required to meet specified soil cleanup levels, (2) disposing of contaminated excavated materials at the Environmental Restoration Disposal Facility (ERDF) at the 200 Areas of the Hanford Site, and (3) backfilling the site with clean soil to match surrounding grade elevation. Excavation was driven by RAOs for direct exposure, protection of groundwater, and protection of the Columbia River. For the respective points of compliance, RAGs, summarized in Table 1, were established for the radionuclide and nonradionuclide contaminants of concern (COCs) in the RDR/RAWP (DOE-RL 2004b). Preliminary waste site COCs were identified in the 300 Area Remedial Action Sampling and Analysis Plan (SAP) (DOE-RL 2004a). Following excavation of the site, final COCs were identified in the Closeout Plan for Waste Site 300-18 (BHI 2005) and are listed in Table 1.

\subsection{SITE DESCRIPTION AND SUPPORTING INFORMATION}

\subsection{SITE HISTORY}

The 300-18 site is located in the 300-FF-2 Operable Unit of the 300 Area, approximately $240 \mathrm{~m}(800 \mathrm{ft}$ ) south of the Treated Effluent Disposal Facility (Figure 1). This site was identified during routine surveillance activities in 1993 as an approximately 4.6- by $6.1-\mathrm{m}$ (15- by $20-\mathrm{ft})$ area containing radiologically contaminated soil, metal shavings, nuts and bolts, and concrete. Following radiological surveys, the site was covered with 0.45 to $0.6 \mathrm{~m} \mathrm{(1.5}$ to $2 \mathrm{ft}$ ) of soil for surface stabilization and posted as an underground radioactive material area. A 1996 survey reported the dimensions of the stabilized area as 12 by $12 \mathrm{~m}$ ( 40 by $40 \mathrm{ft}$ ). 
Table 1. Summary of Remedial Action Goals - Industrial Land Use.

\begin{tabular}{|c|c|c|c|}
\hline cocs & $\begin{array}{c}\text { Direct Exposure } \\
\text { RAG }\end{array}$ & $\begin{array}{c}\text { Soil RAG for } \\
\text { Groundwater Protection } \\
\text { (pCi/g) }\end{array}$ & $\begin{array}{l}\text { Soil RAG for Columbia } \\
\text { River Protection } \\
\text { (pCi/g) }\end{array}$ \\
\hline \multicolumn{4}{|c|}{ Radionuclides } \\
\hline Uranium (total) & $350^{a}$ & $267^{b}$ & $267^{b}$ \\
\hline cocs & $\begin{array}{c}\text { Direct Exposure } \\
\text { RAGs } \\
\text { (mg/kg) }\end{array}$ & $\begin{array}{c}\text { Soil RAG for } \\
\text { Groundwater Protection } \\
(\mathrm{mg} / \mathrm{kg})\end{array}$ & $\begin{array}{l}\text { Soil RAG for Columbia } \\
\text { River Protection } \\
\text { (mg/kg) }\end{array}$ \\
\hline \multicolumn{4}{|c|}{ Nonradionuclides } \\
\hline Arsenic & $58^{\mathrm{C}}$ & $N A^{d}$ & $N A^{d}$ \\
\hline Barium & $4,900^{\mathrm{C}}$ & $N A^{d}$ & $N A^{d}$ \\
\hline Beryllium & $104^{c}$ & $N A^{d}$ & $N A^{d}$ \\
\hline Cadmium & $139^{c}$ & $N A^{d}$ & $N A^{d}$ \\
\hline Chromium & $>1,000,000^{\circ}$ & $N A^{d}$ & $N A^{d}$ \\
\hline Lead & $1,000^{f}$ & $N A^{d}$ & $N A^{d}$ \\
\hline
\end{tabular}

${ }^{\text {a }}$ Listed value is equal to a $15 \mathrm{mrem} / \mathrm{yr}$ dose for the industrial exposure scenario, based on the isotopic distribution of uranium-234, uranium-235, and uranium-238 in the 300 Area.

${ }^{b}$ Value calculated using RESRAD, based on the generic site model (DOE-RL 2004b).

${ }^{c}$ Value calculated based on the inhalation exposure pathway per WAC 173-340-750(4)(b)(ii)(A) or (B).

'RESRAD modeling predicts the constituent will not reach groundwater within 1,000 years based on a generic site profile (DOE-RL 2004b).

${ }^{\circ}$ Cleanup level calculated using WAC 173-340-745(4) resulted in a value greater than pure material (i.e., $>1$ million parts per million).

Cleanup level from WAC 173-340-745 Method A.

$\mathrm{COC}=$ contaminant of concern

NA $\quad=$ not applicable

RAG = remedial action goal

RESRAD = RESidual RADioactivity (dose assessment model)

WAC = Washington Administrative Code 
Figure 1. Hanford Site Map and Location of the 300-18 Site.

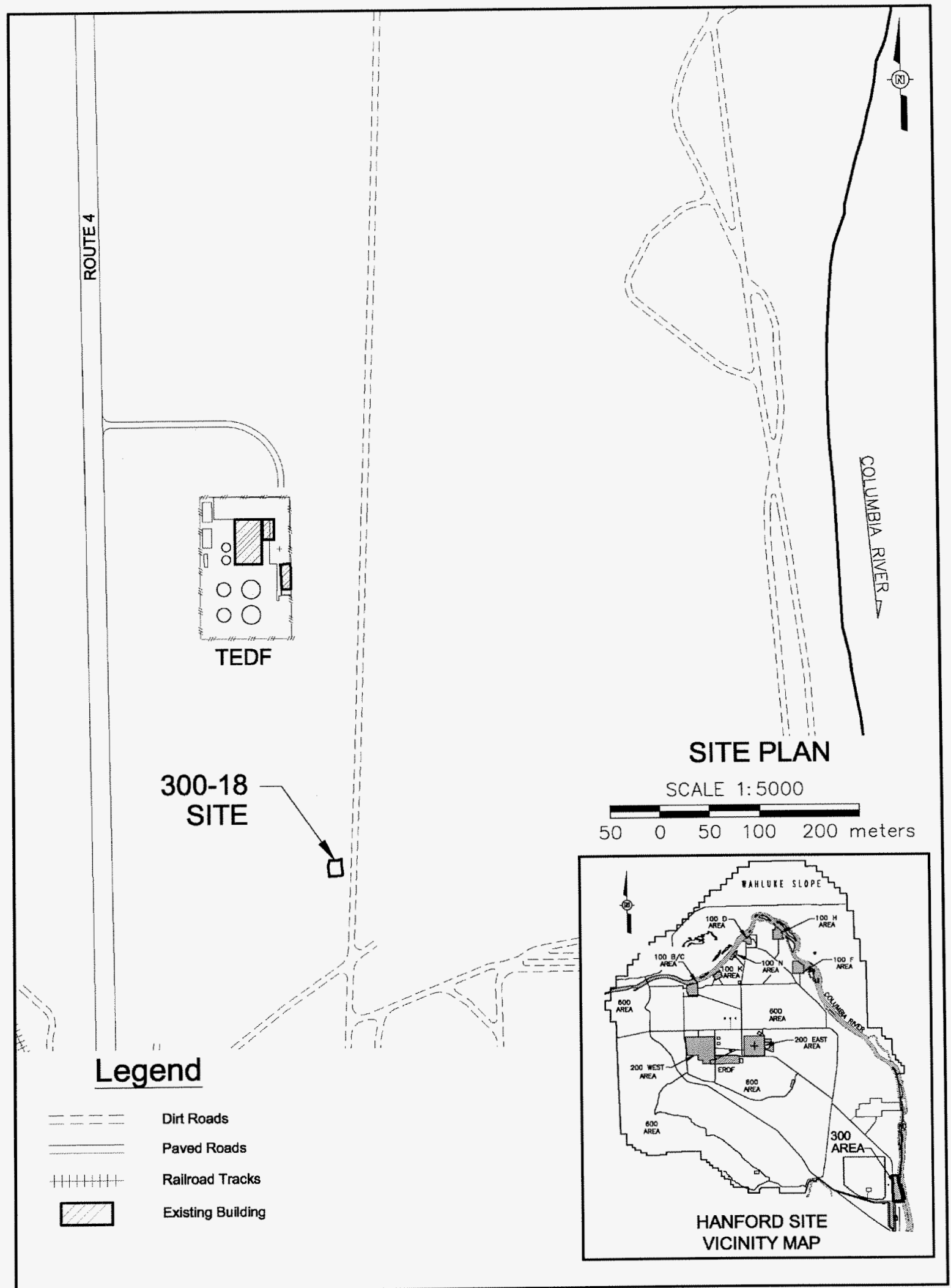




\subsection{SUBSURFACE CONDITIONS}

The soil column (vadose zone) underlying the waste site and extending to groundwater consists of the Hanford and Ringold Formations. The shallower Hanford Formation consists predominantly of medium-dense to dense sand and gravel, with varying amounts of silt and cobble. The underlying Ringold Formation consists of dense, wellcemented gravels with sand and silt interbedding. The Hanford/Ringold contact is approximately 9 to $21 \mathrm{~m} \mathrm{(30}$ to $69 \mathrm{ft}$ ) below the surface grade level.

The long-term groundwater level beneath the site is estimated at El. $104.6 \mathrm{~m}$ (North American Vertical Datum of 1988) based on historical and current information from nearby groundwater wells. Groundwater levels are influenced by the nearby Columbia River and other factors such as atmospheric pressure. The depth to groundwater is

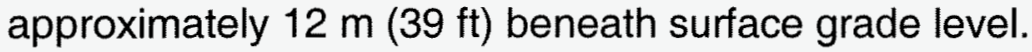

\subsection{REMEDIAL ACTION FIELD ACTIVITIES}

\subsection{EXCAVATION AND DISPOSAL}

Remedial action at the 300-18 site began in December 2004. Excavation of the site included the removal of small quantities of metal shavings, miscellaneous constructiontype debris, and soil. No indications of liquid waste disposal or land disposal restricted materials were observed during excavation. Remedial action excavation was completed in February 2005, with approximately 392 metric tons (432 U.S. tons) removed for transport to ERDF. Pre- and post-remediation topographic civil survey results are depicted in Figures 2 and 3 . The excavation covered an area of approximately $220 \mathrm{~m}^{2}\left(2,370 \mathrm{ft}^{2}\right)$ with an average depth of approximately $1 \mathrm{~m}(3 \mathrm{ft})$.

\subsection{FIELD SCREENING}

A radiological survey was performed in February 2005 after excavation operations were complete at the 300-18 site to provide an initial assessment of attainment of radiological cleanup levels. The results of the survey indicated no residual activity exceeding $50 \mathrm{pCi} / \mathrm{g}$ at the site (Figure 4). 
Figure 2. Pre-Remediation Topographic Plan for the 300-18 Site.

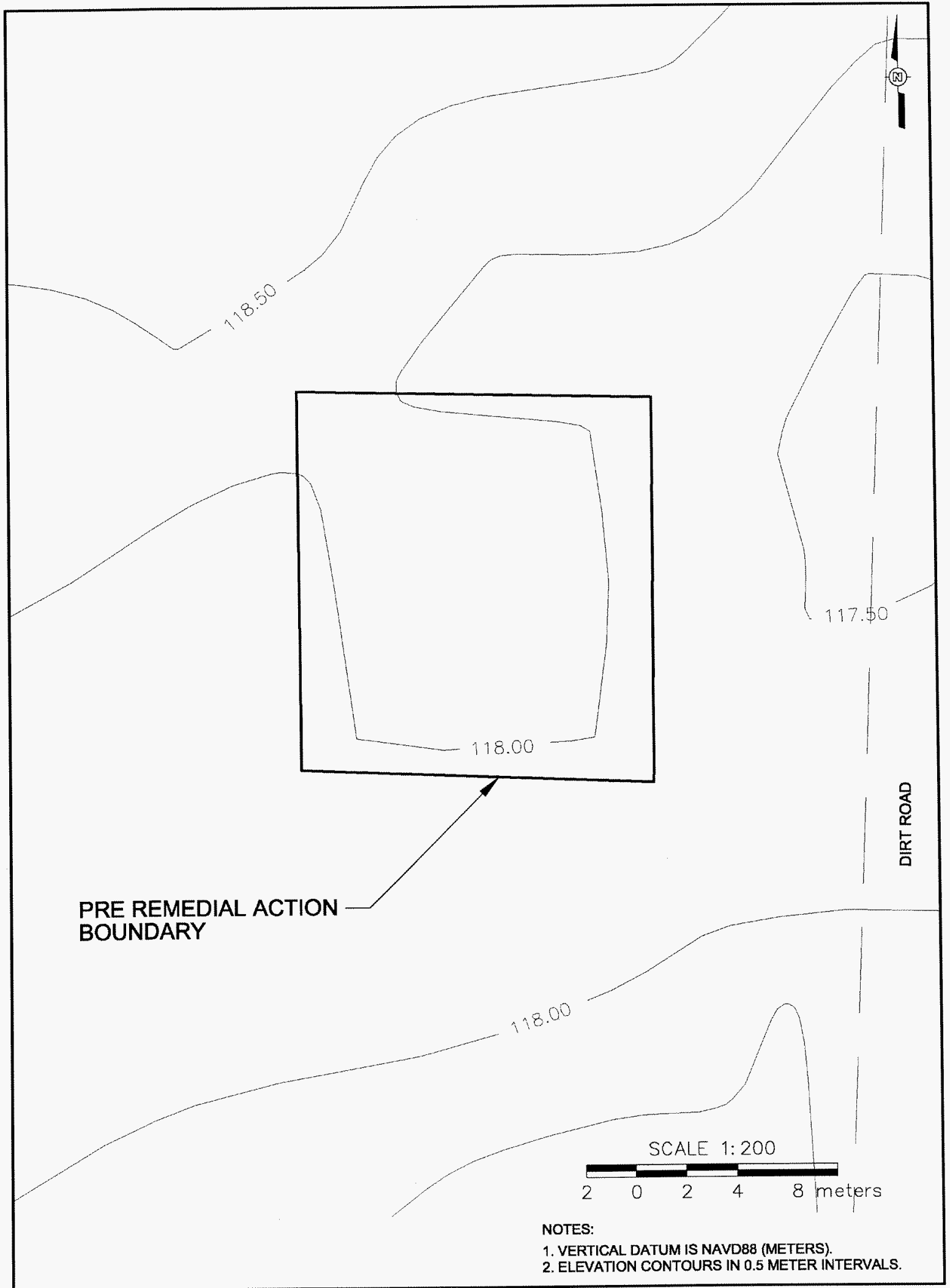


Figure 3. Post-Remediation Topographic Plan for the 300-18 Site.

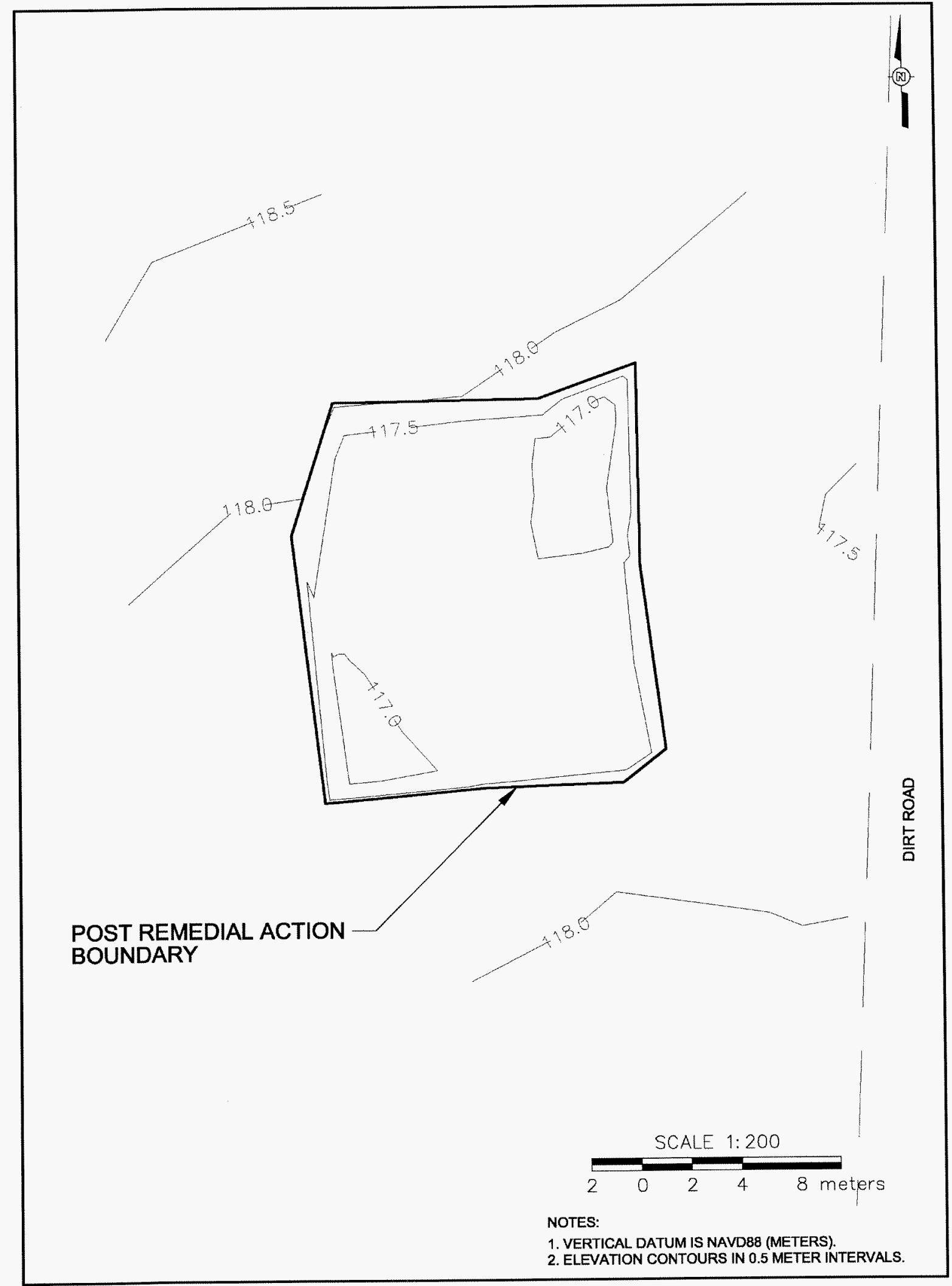




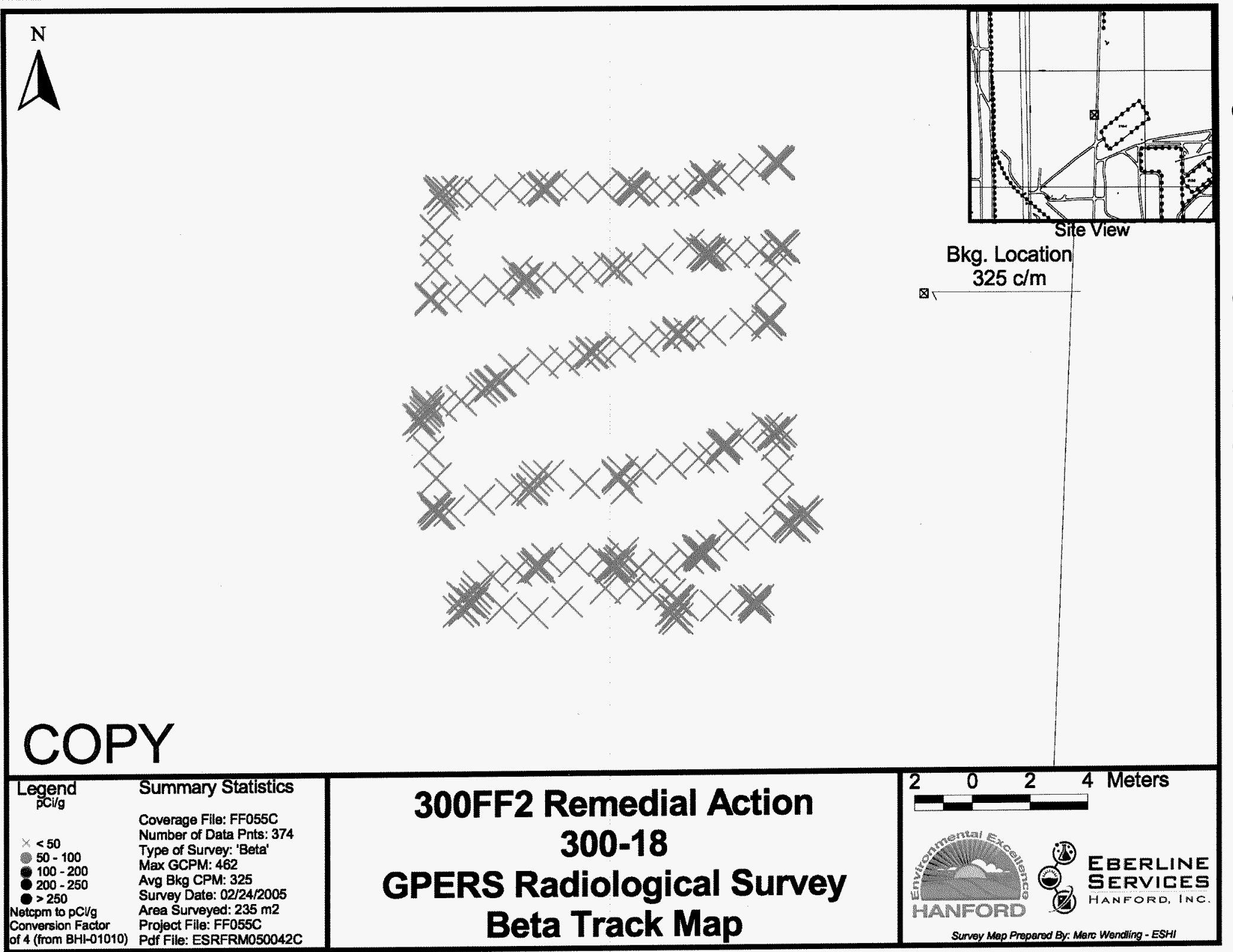

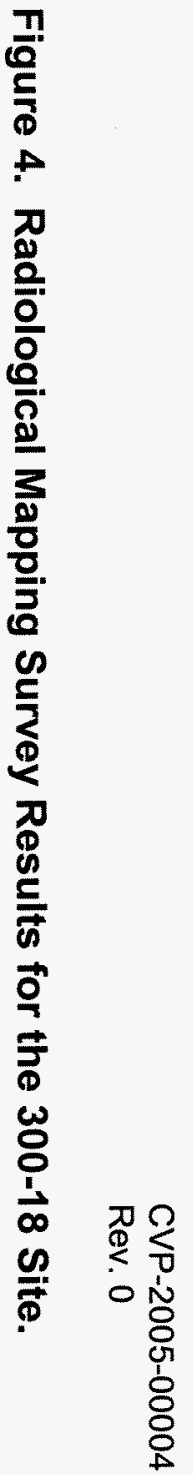




\subsection{BIASED SAMPLING AND ANALYSIS}

Biased samples are typically collected at locations where significant quantities of specific waste streams were unearthed from a common area to help verify the absence of hot spots in the residual soil. At the 300-18 site, waste quantities were small and debris was spread throughout the excavation rather than being concentrated in any discrete area. No containerized liquid was found, and no evidence of historical liquid disposal was identified during the excavation. Consequently, it was determined that radiological surveys and statistical verification sampling would be adequate for site closeout, and biased samples were not collected as per the approved closeout plan (BHI 2005).

\subsection{CLEANUP VERIFICATION SAMPLING AND ANALYSIS}

Final cleanup verification samples were collected on May 25, 2005, to confirm acceptability of residual contaminant concentrations in soil at the 300-18 site. Based on the overall footprint of the area and depth of excavation, the 300-18 site was classified as one shallow zone decision unit. The final verification samples were submitted to offsite laboratories for analysis using approved U.S. Environmental Protection Agency analytical methods as described in the SAP (DOE-RL 2004a).

In accordance with the SAP (DOE-RL 2004a), each verification sample was collected as a composite sample formed by combining soil collected at four random locations within the sampling area (excluding the quality assurance/quality control samples). The sample design methodology and sample location figures are presented in the calculation brief for sample design in Appendix C.

\subsection{CLEANUP VERIFICATION DATA EVALUATION}

This section presents the evaluation and modeling of the 300-18 site cleanup verification data for comparison with the data quality criteria and RAGs.

\subsection{DATA QUALITY ASSESSMENT PROCESS}

A data quality assessment (DQA) is performed to compare the verification sampling approach and resulting analytical data with the sampling and data quality requirements specified by the project objectives and performance specifications.

The DQA for the 300-18 site determined that the data are of the right type, quality, and quantity to support site verification decisions within specified error tolerances. All analytical data were found to be acceptable for decision-making purposes.

The evaluation also found that the sample design was sufficient to support clean site 
verification. The cleanup verification sample analytical data are stored in the Hanford Environmental Information System and are summarized in Appendix A. The detailed DQA is presented in Appendix $B$.

\subsection{CONTAMINANTS OF CONCERN 95\% UPPER CONFIDENCE LIMIT}

The primary statistical calculation to support cleanup verification is the $95 \%$ upper confidence limit (UCL) on the arithmetic mean of the data. Prior to calculating the $95 \%$ UCL, the individual sample results are reviewed and, as appropriate, adjusted per the SAP (DOE-RL 2004a). This process is summarized below.

- Radionuclides: The laboratory-reported value is used in the calculation of the $95 \%$ UCL. In cases where the laboratory does not report a value for data qualified with a " $U$ " (i.e., less than the detection limit), half of the minimum detectable activity is used in the calculation of the $95 \%$ UCL.

- Nonradionuclides: For data flagged with a "U" (i.e., less than detection), a value equal to one-half the practical quantitation limit is used in the calculation of the $95 \%$ UCL, as required by Washington State Department of Ecology regulations (Washington Administrative Code [WAC] 173-340-740[7][g]). If greater than half of the sample results for a given nonradionuclide $\mathrm{COC}$ are below detection, the statistical value is set equal to the maximum concentration detected (i.e., versus computing a $95 \% \mathrm{UCL})$.

Statistical calculations are presented in the 300-18 cleanup verification $95 \%$ UCL calculation brief (Appendix C). Verification sampling summary statistics $(95 \% \mathrm{UCL}$ values) are listed in Table 2. The columns on the left side of Table 2 are the COCs and the $95 \%$ UCL values before subtraction of background. The third column of Table 2 presents the background, where values exist, and the last column presents the statistical values adjusted for background, if appropriate, which become the cleanup verification data set used for evaluation against RAGs. Typically, Hanford Site background concentration values are only subtracted for uranium.

\subsection{SITE-SPECIFIC CLEANUP VERIFICATION MODEL}

A site-specific vadose zone model was not developed for the 300-18 site, as the cleanup verification data set statistical values were all determined to be below statistical background levels, as shown in Table 2. 
CVP-2005-00004

Rev. 0

Table 2. Cleanup Verification Data Set.

\begin{tabular}{|c|c|c|c|}
\hline CoCs & $\begin{array}{c}\text { Shallow Zone 95\% UCL } \\
\text { Statistical Values }\end{array}$ & $\begin{array}{c}\text { Hanford Site } \\
\text { Background }\end{array}$ & $\begin{array}{c}\text { Shallow Zone Cleanup } \\
\text { Verification Data Set }^{\mathrm{a}}\end{array}$ \\
\hline \multicolumn{4}{|c|}{ Radionuclide Concentration $(\mathbf{p C i / g})^{b}$} \\
\hline Uranium (total) & 0.878 & $2.3^{\mathrm{c}}$ & $0(<\mathrm{BG})$ \\
\hline \multicolumn{4}{|c|}{ Nonradionuclide Concentration $(\mathbf{m g} / \mathbf{k g})^{b}$} \\
\hline Arsenic & 2.2 & $6.5^{\mathrm{d}}$ & $2.2(<\mathrm{BG})$ \\
\hline Barium & 62.1 & $132^{\mathrm{d}}$ & $62.1(<\mathrm{BG})$ \\
\hline Beryllium & 0.62 & $1.51^{\mathrm{d}}$ & $0.62(<\mathrm{BG})$ \\
\hline Cadmium & 0.04 & $0.81^{\mathrm{e}}$ & $0.04(<\mathrm{BG})$ \\
\hline Chromium & 6.4 & $18.5^{\mathrm{d}}$ & $6.4(<\mathrm{BG})$ \\
\hline Lead & 3.4 & $10.2^{\mathrm{d}}$ & $3.4(<\mathrm{BG})$ \\
\hline
\end{tabular}

${ }^{a}$ For overburden, anthropogenic background (DOE-RL 1996) and naturally occurring background is subtracted from all radionuclides. For other decision units (e.g., shallow zone and deep zone), naturally occurring background (uranium) is subtracted. Refer to the $95 \%$ UCL calculation brief in Appendix $\mathrm{C}$ for additional details on determination of statistical values.

${ }^{b}$ Laboratory data, including the minimum detectable activity or practical quantitation limit for the individual cleanup verification samples, are included in Appendix $A$ and the $95 \%$ UCL calculation brief in Appendix $C$.

c Value published in Hanford Site Background: Part 2, Soil Background for Radionuclides (DOE-RL 1996).

'Value published in Hanford Site Background: Part 1, Soil Background for Nonradioactive Analytes (DOE-RL 2001).

Value published in Natural Background Soil Metals Concentrations in Washington State (Ecology 1994).

$B G=$ background

$\mathrm{COC}=$ contaminant of concern

$\mathrm{UCL}=$ upper confidence limit

\subsection{RESRAD MODELING}

A site-specific RESidual RADioactivity (RESRAD) model was not developed for the 300-18 site, as the statistical value for total uranium presented in Table 2 was determined to be below the statistical background level as reported in Hanford Site Background: Part 2, Soil Background for Radionuclides (DOE-RL 1996).

\subsection{EVALUATION OF REMEDIAL ACTION GOAL ATTAINMENT FOR INDUSTRIAL LAND USE}

This section demonstrates that remedial actions at the 300-18 site have achieved the RAGs developed to support industrial land use as documented in the RDR/RAWP (DOE-RL 2004b). 


\subsection{DIRECT EXPOSURE SOIL REMEDIAL ACTION GOALS ATTAINED}

\subsubsection{Radionuclides}

5.1.1.1 Direct Comparison to RAGs. The cleanup verification statistical value for total uranium $(0.878 \mathrm{pCi} / \mathrm{g})$ is below the statistical background level $(2.3 \mathrm{pCi} / \mathrm{g})$ and meets the direct exposure RAG of $350 \mathrm{pCi} / \mathrm{g}$, the concentration corresponding to a $15 \mathrm{mrem} / \mathrm{yr}$ excess dose (DOE-RL 2004b). No other radionuclide COCs were identified for the 300-18 site.

5.1.1.2 Radionuclide Risk. Residual concentrations of total uranium at the 300-18 site were detected below the statistical background value and therefore do not contribute to residual excess carcinogenic risk for the site.

\subsubsection{Nonradionuclides}

5.1.2.1 Direct Comparison to RAGs. Table 3 compares the cleanup verification data set statistical values presented in Table 2 to the direct exposure RAGs presented in Table 1. All values are less than statistical background levels and the applicable RAGs.

Table 3. Attainment of Nonradionuclide Direct Exposure Standards - Industrial Land Use.

\begin{tabular}{|c|c|c|c|}
\hline Nonradionuclides & $\begin{array}{c}\mathbf{R A G} \\
(\mathbf{m g} / \mathbf{k g})^{\mathbf{a}}\end{array}$ & $\begin{array}{c}\text { Shallow Zone } \\
\text { Verification Data Set } \\
\text { Values } \\
\text { (mg/kg) }\end{array}$ & $\begin{array}{c}\text { Direct Exposure } \\
\text { RAG Attained? }^{\mathbf{b}}\end{array}$ \\
\hline Arsenic & 58 & 2.2 & Yes \\
\hline Barium & 4,900 & 62.1 & Yes \\
\hline Beryllium & 104 & 0.62 & Yes \\
\hline Cadmium & 139 & 0.04 & Yes \\
\hline Chromium & $>1,000,000^{\mathrm{C}}$ & 6.4 & Yes \\
\hline Lead & 1,000 & 3.4 & Yes \\
\hline
\end{tabular}

${ }^{2}$ Listed value for industrial land use as presented in Remedial Design Report/Remedial Action Work Plan for the 300 Area (DOE-RL 2004b).

${ }^{\mathrm{b}}$ Criterion is comparison to direct exposure RAG.

Direct exposure RAG calculated using WAC 173-340-745(4) resulted in a value greater than pure material (i.e., $>1,000,000$ parts per million).

$\mathrm{RAG}=$ remedial action goal

WAC $=$ Washington Administrative Code

5.1.2.2 Noncarcinogenic Hazard Quotient RAG Attained. For noncarcinogenic COCs, WAC 173-340-740(5)(a) and (b) specify the evaluation of the hazard quotient, which is given as daily intake divided by a reference dose (DOE-RL 2001). Hazard quotients for the nonradionuclide COCs were not calculated because the associated statistical values were less than applicable background values within the shallow zone. 
5.1.2.3 Carcinogenic Risk RAG Attained. For individual nonradionuclide carcinogenic COCs, the WAC 173-340-745(4)(a)(iii) Method C cleanup limits are based on an industrial land-use incremental cancer risk of $1 \times 10^{-5}$. The cumulative excess cancer risk for all nonradionuclide carcinogenic COCs must also be less than $1 \times 10^{-5}$ (EPA et al. 1998). The only nonradionuclide carcinogenic COCs at the 300-18 site were arsenic, beryllium, and cadmium, which were detected at less than applicable background values. Consequently, excess cancer risk values were not calculated.

\subsection{GROUNDWATER REMEDIAL ACTION GOALS ATTAINED}

\subsubsection{Radionuclides}

The cleanup verification statistical value for total uranium $(0.878 \mathrm{pCi} / \mathrm{g})$ is below the statistical background level $(2.3 \mathrm{pCi} / \mathrm{g})$ and meets the RAG for the protection of groundwater $(267 \mathrm{pCi} / \mathrm{g})$, as calculated by RESRAD based on the exposure scenario (DOE-RL 2004b). No other radionuclide COCs were identified for the 300-18 site.

\subsubsection{Nonradionuclides}

None of the nonradionuclide COCs for the 300-18 site are predicted to reach groundwater within 1,000 years based on a generic site profile for the 300 Area (DOE-RL 2004b). Further, none of these COCs were detected above background levels in the cleanup verification data set, as shown in Table 2.

\subsection{COLUMBIA RIVER REMEDIAL ACTION GOALS ATTAINED}

\subsubsection{Radionuclides}

The cleanup verification statistical value for total uranium $(0.878 \mathrm{pCi} / \mathrm{g})$ is below the statistical background level $(2.3 \mathrm{pCi} / \mathrm{g})$ and meets the RAG for the protection of the Columbia River ( $267 \mathrm{pCi} / \mathrm{g}$ ), as calculated by RESRAD based on the exposure scenario and the maximum contaminant level (DOE-RL 2004b). No other radionuclide COCs were identified for the 300-18 site.

\subsubsection{Nonradionuclides}

None of the nonradionuclide COCs for the 300-18 site are predicted to reach groundwater, and thus the Columbia River, within 1,000 years based on a generic site profile for the 300 Area (DOE-RL 2004b). Further, none of these COCs were detected above background levels in the cleanup verification data set, as shown in Table 2. 


\subsection{WAC 173-340 THREE-PART TEST FOR NONRADIONUCLIDES}

The WAC 173-340-740(7)(e) three-part test is applicable to nonradionuclide COCs and consists of the following criteria: (1) the cleanup verification statistical value must be less than the cleanup level, (2) no single detection can exceed two times the cleanup criteria, and (3) the percentage of samples exceeding the cleanup criteria must be less than $10 \%$. The most restrictive RAG (defined as the lowest of the direct exposure, groundwater protection, and river protection RAGs) is used for the test.

All nonradionuclide COCs for the 300-18 site were detected at levels less than applicable background values. Consequently, the WAC 173-340-740(e) three-part test was not performed.

\subsection{EVALUATION OF REMEDIAL ACTION GOAL ATTAINMENT FOR UNRESTRICTED LAND USE}

The information presented in the previous section demonstrates that the cleanup objectives established in the ROD (EPA 2001) for industrial land use have been achieved. In addition, residual soil concentrations indicated that cleanup levels for more stringent land uses may have been achieved for the 300-18 site. The information presented in this section evaluates the remedial action results against cleanup criteria established for unrestricted land use to be implemented at selected sites in the 300-FF-2 Operable Unit through the Explanation of Significant Differences for the 300-FF-2 Operable Unit Record of Decision (ESD) (EPA 2004).

The 300 Area unrestricted land-use scenario is represented by an individual in a ruralresidential setting. The exposure pathways considered in estimating dose from radionuclides in soil are inhalation; soil ingestion; ingestion of crops, meat, fish, drinking water, and milk; and external gamma exposure. This individual is conservatively assumed to spend $80 \%$ of his/her lifetime onsite. It is assumed that drinking water and irrigation water are obtained from groundwater, as impacted by the waste site.

Unrestricted land-use cleanup levels for chemicals or nonradionuclides are based on WAC 173-340-740(3), which assumes that the exposure pathway for residual contamination will be from ingestion of contaminated soil. Soil cleanup levels are calculated using the equations provided by WAC 173-340-740(3) for carcinogens and for noncarcinogens. For both carcinogens and noncarcinogens, the calculations assume that a resident with an average body weight $16 \mathrm{~kg}(35 \mathrm{lb})$ over the period of exposure ingests soil at a rate of $200 \mathrm{mg} /$ day $(73 \mathrm{~g} / \mathrm{yr}$ [2.6 oz/yr]), with a frequency of contact of $100 \%$ and a gastrointestinal absorption rate of $100 \%$. For carcinogens, the calculation is based on achieving a lifetime cancer risk goal of 1 in $1,000,000\left(1 \times 10^{-6}\right)$ for an exposure duration of 6 years and a lifetime of 75 years. For noncarcinogens, the calculation is based on achieving a hazard quotient of 1 . 
The key assumptions in the 300 Area unrestricted land-use scenario that affect groundwater protection are irrigation at agronomic rates $(76 \mathrm{~cm} / \mathrm{yr}[30 \mathrm{in} . / \mathrm{yr}])$, surface vegetation resulting in an evapotranspiration coefficient of $91 \%$, and the change in the exposure pathway to include drinking water ingestion. Details of this land-use scenario and associated RAGs are documented in the ESD (EPA 2004).

A comparison of the 300-18 site cleanup verification data set to the cleanup objectives for unrestricted land use as established in the ESD (EPA 2004) is presented in the following section.

\subsection{DIRECT EXPOSURE SOIL REMEDIAL ACTION GOALS ATTAINED}

\subsubsection{Radionuclides}

6.1.1.1 Direct Comparison to RAGs. The cleanup verification statistical value for total uranium $(0.878 \mathrm{pCi} / \mathrm{g})$ is below the statistical background level $(2.3 \mathrm{pCi} / \mathrm{g})$ and meets the direct exposure RAG of $56 \mathrm{pCi} / \mathrm{g}$, the concentration corresponding to a $15 \mathrm{mrem} / \mathrm{yr}$ excess dose (EPA 2004). No other radionuclide COCs were identified for the 300-18 site.

6.1.1.2 Radionuclide Risk. Residual concentrations of total uranium at the 300-18 site were detected below the statistical background value and therefore do not contribute to residual excess carcinogenic risk for the site.

\subsubsection{Nonradionuclides}

6.1.2.1 Direct Comparison to RAGs. Table 4 compares the cleanup verification data set statistical values presented in Table 2 to the direct exposure RAGs for unrestricted land use. All values are less than statistical background levels and the applicable RAGs.

6.1.2.2 Noncarcinogenic Hazard Quotient. For noncarcinogenic COCs, WAC 173-340-740(5)(a) and (b) specify the evaluation of the hazard quotient, which is given as daily intake divided by a reference dose (DOE-RL 2001). Hazard quotients for nonradionuclide COCs were not calculated because the associated statistical values were less than applicable background values within the shallow zone.

6.1.2.3 Carcinogenic Risk. For individual nonradionuclide carcinogenic COCs, the WAC 173-340-750(3) Method B cleanup limits are based on an unrestricted land-use incremental cancer risk of $1 \times 10^{-6}$. The cumulative excess cancer risk for all nonradionuclide carcinogenic COCs must also be less than $1 \times 10^{-5}$ (EPA et al. 1998). The only nonradionuclide carcinogenic COCs at the 300-18 site were arsenic, beryllium, and cadmium, which were detected at less than applicable background values.

Consequently, excess cancer risk values were not calculated. 
Table 4. Attainment of Nonradionuclide Direct Exposure Standards - Unrestricted Land Use.

\begin{tabular}{|c|c|c|c|}
\hline Nonradionuclides & $\begin{array}{c}\text { RAG } \\
(\mathbf{m g} / \mathbf{k g})^{\mathbf{a}}\end{array}$ & $\begin{array}{c}\text { Shallow Zone } \\
\text { Verification Data Set } \\
\text { Values } \\
(\mathbf{m g} / \mathbf{k g})\end{array}$ & $\begin{array}{c}\text { Direct Exposure } \\
\text { RAG Attained } \text { ? }^{\mathbf{b}}\end{array}$ \\
\hline Arsenic & 20 & 2.2 & Yes \\
\hline Barium & 1,600 & 62.1 & Yes \\
\hline Beryllium & 10.4 & 0.62 & Yes \\
\hline Cadmium & 13.9 & 0.04 & Yes \\
\hline Chromium & 120,000 & 6.4 & Yes \\
\hline Lead & 353 & 3.4 & Yes \\
\hline
\end{tabular}

a Listed value for unrestricted land use as presented in Explanation of Significant Differences for the 300-FF-2 Operable Unit Record of Decision (EPA 2004).

${ }^{b}$ Criterion is comparison to direct exposure RAG.

$\mathrm{RAG}=$ remedial action goal

\subsection{GROUNDWATER REMEDIAL ACTION GOALS ATTAINED}

\subsubsection{Radionuclides}

The cleanup verification statistical value for total uranium $(0.878 \mathrm{pCi} / \mathrm{g})$ is below the statistical background level $(2.3 \mathrm{pCi} / \mathrm{g})$ and meets the RAG for the protection of groundwater $(37 \mathrm{pCi} / \mathrm{g})$, as calculated by RESRAD based on the exposure scenario (EPA 2004). No other radionuclide COCs were identified for the 300-18 site.

\subsubsection{Nonradionuclides}

None of the nonradionuclide COCs for the 300-18 site are predicted to reach groundwater within 1,000 years based on a generic site profile for the 300 Area (DOE-RL 2004b). Further, none of these COCs were detected above background levels in the cleanup verification data set, as shown in Table 2.

\subsection{COLUMBIA RIVER REMEDIAL ACTION GOALS ATTAINED}

\subsubsection{Radionuclides}

The cleanup verification statistical value for total uranium $(0.878 \mathrm{pCi} / \mathrm{g})$ is below the statistical background level $(2.3 \mathrm{pCi} / \mathrm{g})$ and meets the RAG for the protection of the Columbia River (74 pCi/g), as calculated by RESRAD based on the exposure scenario (DOE-RL 2004b). No other radionuclide COCs were identified for the 300-18 site. 


\subsubsection{Nonradionuclides}

None of the nonradionuclide COCs for the 300-18 site are predicted to reach groundwater, and thus the Columbia River, within 1,000 years based on a generic site profile for the 300 Area (DOE-RL 2004b). Further, none of these COCs were detected above background levels in the cleanup verification data set, as shown in Table 2.

\subsection{WAC 173-340 THREE-PART TEST FOR NONRADIONUCLIDES}

All nonradionuclide COCs for the $300-18$ site were detected at levels less than applicable background values. Consequently, the WAC 173-340-740(e) three-part test was not performed.

\subsection{STATEMENT OF PROTECTIVENESS}

This cleanup verification package demonstrates that remedial action at the 300-18 site has achieved the RAOs and corresponding RAGs established in the ROD (EPA 2001) and RDR/RAWP (DOE-RL 2004b). The contaminated materials from the site have been excavated and disposed at ERDF. The remaining soil at the 300-18 site has been sampled, analyzed, and evaluated. Results indicate that the site supports future land uses that can be represented (or bounded) by the industrial land-use scenario and poses no threat to groundwater or the Columbia River. Consequently, the 300-18 site is verified to be remediated in accordance with the ROD and may be backfilled.

Because residual soil concentrations indicated that cleanup levels for more stringent land uses may have been achieved for the 300-18 site, a supplemental evaluation was performed against the unrestricted land-use RAGs established for the 300 Area in the ESD (EPA 2004). This evaluation demonstrated that the results of verification sampling do not preclude any future uses (as bounded by the rural-residential scenario) and allow unrestricted use of shallow zone soils. In consideration of this and because the site has no deep zone, no institutional controls are required at the 300-18 site.

\subsection{REFERENCES}

65 FR 76708, "National Primary Drinking Water Regulations; Radionuclides; Final Rule," Federal Register, Vol. 65, No. 236, p. 76708, December 7, 2000.

BHI, 2001, Calculation of Total Uranium Activity Corresponding to a Maximum Contaminant Level for Total Uranium of 30 Micrograms per Liter in Groundwater, 0100X-CA-V0038, Rev. 0, Bechtel Hanford, Inc., Richland, Washington. 
BHI, 2005, Closeout Plan for Waste Site 300-18, CCN 121190, Bechtel Hanford, Inc., Richland, Washington.

Comprehensive Environmental Response, Compensation, and Liability Act of 1980, 42 U.S.C. 601 , et seq.

DOE Order 5400.5, Radiation Protection of the Public and the Environment, U.S. Department of Energy, Washington, D.C.

DOE-RL, 1996, Hanford Site Background: Part 2, Soil Background for Radionuclides, DOE/RL-96-12, Rev. 0, U.S. Department of Energy, Richland Operations Office, Richland, Washington.

DOE-RL, 1998, Tri-Party Agreement Handbook Management Procedures, RL-TPA-90-0001, Guideline Number TPA-MP-14, "Maintenance of the Waste Information Data System (WIDS)," U.S. Department of Energy, Richland Operations Office, Richland, Washington.

DOE-RL, 2001, Hanford Site Background: Part 1, Soil Background for Nonradioactive Analytes, DOE/RL-92-24, Rev. 4, U.S. Department of Energy, Richland Operations Office, Richland, Washington.

DOE-RL, 2004a, 300 Area Remedial Action Sampling and Analysis Plan, DOE/RL-2001-48, Rev. 1, U.S. Department of Energy, Richland Operations Office, Richland, Washington.

DOE-RL, 2004b, Remedial Design Report/Remedial Action Work Plan for the 300 Area, DOE/RL-2001-47, Rev. 1, U.S. Department of Energy, Richland Operations Office, Richland, Washington.

Ecology, 1994, Natural Background Soil Metals Concentrations in Washington State, Publication No. 94-115, Washington State Department of Ecology, Olympia, Washington.

Ecology, EPA, and DOE, 1989, Hanford Federal Facility Agreement and Consent Order, 2 vols., as amended, Washington State Department of Ecology, U.S. Environmental Protection Agency, and U.S. Department of Energy, Olympia, Washington.

EPA, 2001, Record of Decision for the 300-FF-2 Operable Unit, Hanford Site, U.S. Environmental Protection Agency, Region 10, Seattle, Washington.

EPA, 2004, Explanation of Significant Differences for the 300-FF-2 Operable Unit Record of Decision, U.S. Environmental Protection Agency, Region 10, Seattle, Washington. 
EPA, Ecology, and RL, 1998, Environmental Restoration Contractor Meeting Minutes Remedial Action and Waste Disposal Unit Managers' Meeting -- 100 Area, Draft, dated July 6, 1998, U.S. Environmental Protection Agency, Washington State Department of Ecology, and U.S. Department of Energy, Richland Operations Office, Richland, Washington.

WAC 173-340, 1996, "Model Toxics Control Act - Cleanup" Washington Administrative Code. 
APPENDIX A

SUMMARY OF VERIFICATION SOIL SAMPLING AND ANALYTICAL RESULTS 
CVP-2005-00004

Rev. 0

A-ii 
Table A-1. 300-18 Shallow Zone Cleanup Verification Data.

\begin{tabular}{|c|c|c|c|c|c|c|c|c|c|c|c|c|c|c|c|c|c|}
\hline \multirow{2}{*}{$\begin{array}{c}\text { Sampling } \\
\text { Area }\end{array}$} & \multirow{2}{*}{$\begin{array}{c}\text { HEIS } \\
\text { Number }\end{array}$} & \multirow{2}{*}{$\begin{array}{c}\text { Sample } \\
\text { Date }\end{array}$} & \multicolumn{3}{|c|}{ Arsenic } & \multicolumn{3}{|c|}{ Barium } & \multicolumn{3}{|c|}{ Beryllium } & \multicolumn{3}{|c|}{ Cadmium } & \multicolumn{3}{|c|}{ Chromium } \\
\hline & & & $\mathrm{mg} / \mathrm{kg}$ & $Q$ & PQL & $\mathrm{mg} / \mathrm{kg}$ & $Q$ & PQL & $\mathrm{mg} / \mathrm{kg}$ & $a$ & PQL & $\mathrm{mg} / \mathrm{kg}$ & $Q$ & PQL & $\mathrm{mg} / \mathrm{kg}$ & $Q$ & $P Q L$ \\
\hline A-1 & J036W6 & $5 / 25 / 05$ & $1.5 E+00$ & & $4.4 \mathrm{E}-01$ & $5.77 E+01$ & & $2 \mathrm{E}-02$ & $5.2 E-01$ & & $1 E-02$ & 3.E-02 & $u$ & $3 E-02$ & 4.7E+00 & & $7 E-02$ \\
\hline $\begin{array}{l}\text { Duplicate of } \\
\text { J036W6 }\end{array}$ & J036X0 & $5 / 25 / 05$ & $1.8 E+00$ & & $4.2 \mathrm{E}-01$ & $6.33 E+01$ & & $2 \mathrm{E}-02$ & 5.0E-01 & & $9 E-03$ & 3.E-02 & $\mathrm{U}$ & $3 E-02$ & $4.7 E+00$ & & 7E-02 \\
\hline $\begin{array}{c}\text { Split of } \\
\text { J036W6 }\end{array}$ & J036X1 & $5 / 25 / 05$ & $2.2 E+\infty 0$ & & $1.0 E+00$ & $6.77 E+01$ & & $2.06 E+01$ & 2.8E-01 & $\mathrm{J}$ & $5.2 \mathrm{E}-01$ & $5.2 E-01$ & U & $5.2 \mathrm{E}-01$ & $7.4 \mathrm{E}+00$ & & $1.0 E+00$ \\
\hline$A-2$ & J036W7 & $5 / 25 / 05$ & $2.0 E+00$ & & $4.5 E-01$ & $5.80 E+01$ & & $2 E-02$ & 5.3E-01 & & $1 E-02$ & 3.E-02 & $\mathrm{U}$ & $3 E-02$ & $5.4 \mathrm{E}+00$ & & $7 E-02$ \\
\hline$A-3$ & J036W8 & $5 / 25 / 05$ & $2.0 \mathrm{E}+00$ & & $4.5 \mathrm{E}-01$ & $6.34 E+01$ & & $2 E-02$ & $6.5 \mathrm{E}-01$ & & $1 \mathrm{E}-02$ & 3.E-02 & $U$ & $3 E-02$ & $6.9 E+00$ & & $7 E-02$ \\
\hline$A-4$ & J036W9 & $5 / 25 / 05$ & $2.2 \mathrm{E}+00$ & & 4.1E-01 & $5.88 E+01$ & & $2 E-02$ & $5.9 \mathrm{E}-01$ & & $9 \mathrm{E}-03$ & 4.E-02 & & $3 E-02$ & $5.7 E+00$ & & $6 \mathrm{E}-02$ \\
\hline
\end{tabular}

\begin{tabular}{|c|c|c|c|c|c|c|c|c|}
\hline \multirow{2}{*}{$\underset{\text { Area }}{\text { Sampling }}$} & \multirow{2}{*}{$\begin{array}{c}\text { HEIS } \\
\text { Number }\end{array}$} & \multirow{2}{*}{$\begin{array}{c}\text { Sample } \\
\text { Date }\end{array}$} & \multicolumn{3}{|c|}{ Lead } & \multicolumn{3}{|c|}{ Uranium (Total) } \\
\hline & & & $\mathrm{mg} / \mathrm{kg}$ & $Q$ & PQL & $\mathrm{pCi} / \mathrm{g}$ & $Q$ & MDA \\
\hline$A-1$ & J036W6 & $5 / 25 / 05$ & $2.7 E+00$ & & $2.5 \mathrm{E}-01$ & $4.22 E-01$ & & $2.5 \mathrm{E}-01$ \\
\hline $\begin{array}{l}\text { Duplicate of } \\
\text { J036W6 }\end{array}$ & J036X0 & $5 / 25 / 05$ & $2.8 E+00$ & & 2.4E-01 & 7.81E-01 & & 1.7E-01 \\
\hline $\begin{array}{c}\text { Split of } \\
\text { J036W6 }\end{array}$ & J036X1 & $5 / 25 / 05$ & $2.6 E+00$ & & $1.0 E+00$ & $1.38 E+00$ & & $9.12 E-02$ \\
\hline$A-2$ & J036W7 & $5 / 25 / 05$ & $3.0 E+00$ & & $2.5 \mathrm{E}-01$ & $5.56 \mathrm{E}-01$ & & $2.5 E-01$ \\
\hline$A-3$ & J036W8 & $5 / 25 / 05$ & $3.2 E+00$ & & 2.5E-01 & $6.38 E-01$ & & $1.9 \mathrm{E}-01$ \\
\hline$A-4$ & J036W9 & $5 / 25 / 05$ & $3.6 E+00$ & & 2.3E-01 & $1.018 \mathrm{E}+00$ & & $2.1 E-01$ \\
\hline
\end{tabular}

HEIS = Hanford Environmental Information System

$\mathrm{J}=$ estimate

MDA = minimum detectable activity

$\mathrm{PQL}=$ practical quantitation limit

$\mathrm{Q}$ = qualifier

$U \quad=$ Analyte is below detection limits of the method and instruments used (not detected) 
CVP-2005-00004

Rev. 0

A-2 
CVP-2005-00004

Rev. 0

APPENDIX B

DATA QUALITY ASSESSMENT

$B-i$ 
CVP-2005-00004

Rev. 0 
CVP-2005-00004

Rev. 0

\section{APPENDIX B}

\section{DATA QUALITY ASSESSMENT FOR THE 300-18 WASTE SITE}

\section{B1.1 OVERVIEW}

This DQA was performed in accordance with BHI-EE-01, Environmental Investigations Procedures. Specific data quality objectives for the site are found in the 300 Area Remedial Action Sampling and Analysis Plan (SAP) (DOE-RL 2004a). The DQA is based on the guidelines presented in Guidance for Data Quality Assessment (EPA 2000). Statistical tests used in this DQA were performed as specified in the SAP and the Remedial Design Report/Remedial Action Work Plan for the 300 Area (RDR/RAWP) (DOE-RL 2004b). This DQA involves the scientific and statistical evaluations to determine if the data are of the right type, quality, and quantity to support the intended use (i.e., closeout decisions [EPA 2000]). This DQA completes the data life cycle (i.e., planning, implementation, and assessment) that was initiated by the data quality objectives process.

Prior to performing statistical tests, the field logbook (BHI 2005a), sample design, and sample analytical data are evaluated. A portion of the cleanup verification sample analytical data are validated for compliance requirements (DOE-RL 2004b). Data evaluation is performed to determine if the laboratory carried out all steps required by the SAP (DOE-RL 2004a) and the laboratory contract governing the conduct of the analysis and reporting of the data. This assessment also examines the available laboratory data to determine what analytes are present or absent in a sample and the degree of overall uncertainty associated with that determination. Data validation is done in accordance with validation procedures (BHI 2000a, 2000b) as part of data evaluation. After data evaluation and validation, the appropriate statistical test is performed on the adjusted raw analytical data (see calculation briefs in Appendix $\mathrm{C}$ ) to determine statistical values for each contaminant. The cleanup verification sample analytical data are stored in the Hanford Environmental Information System and are summarized in Appendix A. 


\section{B1.2 LABORATORY QUALITY ASSURANCE/QUALITY CONTROL MEASURES}

All verification samples are subject to laboratory-specific quality assurance (QA) requirements, including instrument procurement, maintenance, calibration, and operation. Additional laboratory quality control $(\mathrm{QC})$ checks are performed as specified by the analytical method, at a rate of once per sample delivery group (SDG), or once for every 20 samples, whichever is more frequent. Laboratory internal QC checks include the following:

- Laboratory Contamination: Each analytical batch contains a laboratory (method) blank (material of similar composition as the samples with known/minimal contamination of the analytes of interest) carried through the complete analytical process. The method blank is used to evaluate false-positive results in samples due to contamination during handling at the laboratory.

- Analytical Accuracy: For most analyses, known quantities of representative analytes of interest (matrix spike [MS]) are added to a separate aliquot of a sample from the analytical batch. The recovery percentage of the added MS is used to evaluate analytical accuracy. For analyses not amenable to MS techniques (e.g., gamma energy analysis) or where analytical recovery is corrected via internal standards (e.g., alpha spectral analyses), accuracy is evaluated from recovery of the QC reference sample (e.g., laboratory control spike or blank spike sample).

- Analytical Precision: Separate aliquots removed from one or more of the same sample containers (replicate samples) are analyzed for each analytical batch. The replicate sample results (evaluated as relative percent differences [RPDs]) are used to assess analytical precision.

- QC Reference Samples: A QC reference sample is prepared from an independent standard at a concentration other than that used for calibration, but within the calibration range. Reference samples provide an independent check on analytical technique, methodology, and quantitation.

Laboratories are also subject to periodic and random assessments of overall performance. These assessments are performed by the Bechtel Hanford, Inc. QA group to ensure that the laboratories are performing within laboratory contract requirements.

\section{B1.3 DATA VALIDATION}

The final laboratory data package for SDG H3172 was validated to Level C per BHI-EE-01, Procedure 2.5, "Data Package Validation Process," by a third-party validator. Level $\mathrm{C}$ validation procedures are specified in Data Validation Procedure for Chemical Analysis (BHI 2000a) and Data Validation Procedure for Radiochemical Analysis (BHI 2000b). 
Use of level $\mathrm{C}$ validation procedures included the review of the following items, as appropriate, for each analytical method:

- Sample holding times

- Method blanks

- MS recovery

- Surrogate recovery

- MS/matrix spike duplicate results

- Sample replicates

- Associated batch laboratory control sample results

- Achievement of required (or contractual) detection limits (RDLs)

- Data package completeness.

The laboratory QA/QC was evaluated for precision, accuracy, completeness, and RDLs pursuant to the SAP (DOE-RL 2004a). The organization performing the data validation reported that, of the data validated, the laboratory met the standards of performance for precision $( \pm 30 \%)$, accuracy $( \pm 30 \%)$, and completeness $(>90 \%)$. Comparison of the $\mathrm{RDL}$ with the respective MDA or PQL is discussed in Section B1.4.

The validation process did not identify any major or minor deficiencies in the sample results. Consequently, no data qualifiers were assigned to the reported results through the validation process. Additional information is provided in the associated validation reports (BHI 2005b, 2005c).

\section{B1.4 DATA EVALUATION}

The context for assessing the data includes evaluating the sample data using the statistical methodology of the SAP (DOE-RL 2004a) (included in the calculation brief excerpts in Appendix C) and a comparison of analytical results to the parameters specified in the SAP. This section summarizes the results of the comparison and presents an evaluation of the affected data.

\section{B1.4.1 RDL Comparison}

Reported analytical detection levels for nondetected analytes were compared to the RDLs specified in the SAP (DOE-RL 2005a). When detected results are obtained, evaluation of detection limits is not performed. The data validation and supplemental data evaluation noted no analyses for which the detection limits (MDA or PQL) were above SAP RDLs for nondetected analytes.

\section{B1.4.2 Precision and Accuracy Evaluation}

Analytical accuracy and precision were evaluated by examination of the percent recovery and RPD of analytical spikes (MS and/or laboratory control samples) between the main and duplicate samples. Only the contaminants of concern (COCs) detected at more than five times the detection limit are used for data analysis with respect to 
accuracy and precision. The RPDs for all laboratory duplicates and the recoveries for all laboratory spikes were within acceptable limits.

\section{B1.5 FIELD QUALITY ASSURANCE/QUALITY CONTROL}

Field QA/QC measures were used to assess potential sources of error and crosscontamination of soil samples that could bias results. Field QA/QC samples included the following:

- Duplicate J036X0, associated with sample J036W6, and

- Split J036X1, associated with sample J036W6.

All main and QA/QC sample results are presented in Appendix A.

\section{B1.5.1 Field Duplicate Samples}

Duplicate samples were collected to provide a relative measure of the degree of local heterogeneity in the sampling medium, unlike laboratory duplicates that are used to evaluate precision in the analytical process. The field duplicates are evaluated by computing the RPD of the duplicate samples for each COC. Only analytes with values more than five times the contractual RDLs for both the main and duplicate samples are compared. Based on these criteria, RPD analysis was not required for any duplicate pairs. The $95 \%$ upper confidence limit calculation brief in Appendix $C$ provides details on duplicate pair evaluation and RPD calculation.

\section{B1.5.2 Field Split Samples}

Split samples were collected to provide a relative measure of the degree of variability in the sampling, sample handling, and analytical techniques used by commercial laboratories. The field main and split samples are evaluated by computing the RPD of the split samples for each $\mathrm{COC}$ to determine the usability of the verification data. The U.S. Environmental Protection Agency Contract Laboratory Program duplicate sample comparison methodology, USEPA Contract Laboratory Program National Functional Guidelines for Inorganic Data Review (EPA 1994), is used as an initial test of the data from the splits. Only analytes that had values more than five times the contractual RDL for both the main and split sample were compared. Based on these criteria, RPD analysis was not required for any split pairs. The $95 \%$ upper confidence limit calculation brief in Appendix C provides details on split pair evaluation and RPD calculation.

\section{B1.6 SUITABILITY OF DATA}

The DQA for the 300-18 site determined that the data are of the right type, quality, and quantity to support site cleanup verification decisions within specified error tolerances. The evaluation verified that the sample design was sufficient for the purpose of clean 
site verification. All analytical data were found to be acceptable for decision-making purposes and acceptable for calculating the required statistical values.

\section{B2.0 REFERENCES}

BHI, 2000a, Data Validation Procedure for Chemical Analysis, BHI-01435, Rev. 0, Bechtel Hanford, Inc., Richland, Washington.

BHI, 2000b, Data Validation Procedure for Radiochemical Analysis, BHI-01433, Rev. 0, Bechtel Hanford, Inc., Richland, Washington.

BHI, 2005a, 300-FF-1/2 Analytical Field Services Logbook, EFL-1395-8, Bechtel Hanford, Inc., Richland, Washington.

BHI, 2005b, Data Validation Package - Inorganics (SDG No. H3172), Bechtel Hanford, Inc., Richland, Washington.

BHI, 2005c, Data Validation Package - Radiochemistry (SDG No. 3172), Bechtel Hanford, Inc., Richland, Washington.

BHI-EE-01, Environmental Investigations Procedures, Bechtel Hanford, Inc., Richland, Washington.

DOE-RL, 2004a, 300 Area Remedial Action Sampling and Analysis Plan, DOE/RL-2001-48, Rev. 1, U.S. Department of Energy, Richland Operations Office, Richland, Washington.

DOE-RL, 2004b, Remedial Design Report/Remedial Action Work Plan for the 300 Area, DOE/RL-2001-47, Rev. 1, U.S. Department of Energy, Richland Operations Office, Richland, Washington.

EPA, 1994, USEPA Contract Laboratory Program National Functional Guidelines for Inorganic Data Review, EPA 540/R-94/013, U.S. Environmental Protection Agency, Washington, D.C.

EPA, 2000, Guidance for Data Quality Assessment, EPA QA/G-9, QA00 Update, U.S. Environmental Protection Agency, Office of Environmental Information, Washington, D.C. 
CVP-2005-00004

Rev. 0

B-6 
CVP-2005-00004

Rev. 0

APPENDIX C

CALCULATION BRIEF EXCERPTS

C-i 
CVP-2005-00004

Rev. 0

\section{DISCLAIMER FOR CALCULATIONS}

The attached calculations have been generated for a specific purpose and task. Use of these calculations by persons who do not have access to all pertinent facts may lead to incorrect conclusions and/or results. Before applying these calculations to your work, the underlying basis, rationale, and other pertinent information relevant to these calculations must be thoroughly reviewed with appropriate ERC officials or other authorized personnel. The Hanford Site ERC is not responsible for the use of a calculation not under its direct control. 


\section{CALCULATION BRIEFS}

The following calculation briefs have been prepared in accordance with BHI-DE-01, Design Engineering Procedures Manual, EDPI-4.37-01, "Project Calculations," Bechtel Hanford, Inc., Richland, Washington.

300-18 Site Shallow Zone Sampling Plan, 0300X-CA-V0054, Rev. 0, Bechtel Hanford, Inc., Richland, Washington.

300-18 Cleanup Verification 95\% UCL Calculation, 0300X-CA-V0053, Rev. 0, Bechtel Hanford, Inc., Richland, Washington.

NOTE: The calculation briefs referenced in this appendix are kept in the active Environmental Restoration Contractor project files and are available upon request. When the project is completed, the files will be stored in a U.S. Department of Energy, Richland Operations Office repository. Only excerpts of the calculation briefs are included in this appendix. 
CVP-2005-00004

Rev. 0

C-2 
CVP-2005-00004

Rev. 0

\section{CALCULATION COVER SHEET}

Project Title:

Area

Discipline

Subject

Computer Program
300-18 Site Sample Design

Job No. 300 Area

Environmental Engineering Calc. No. 0300X-CA-V0054

300-18 Site Shallow Zone Sampling Plan

Excel Program No. Excel 2003

The attached calculations have been generated to document compliance with established cleanup levels. These documents should be used in conjuction with other relevent documents in the administrative record.

Committed Calculation

区

Preliminary

Superseded

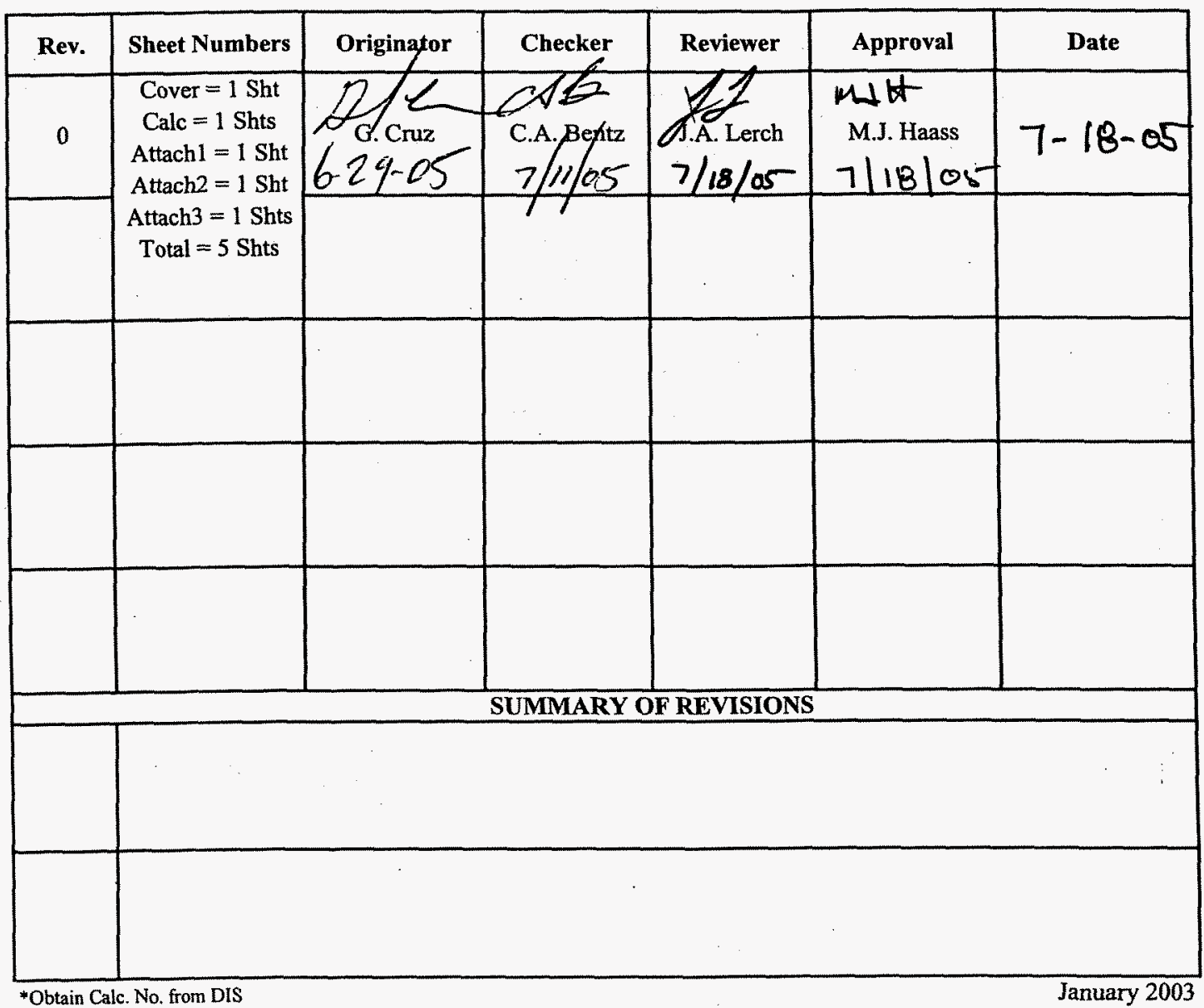

DE01-437.03 


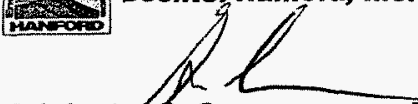

Originator G. Cruz Project

300-18 Site Sample Design

Date $6 / 29 / 2005$

Subject 300-18 Site Shallow Zone Sampling Plan
Calc. No. 0300X-CA-V0054 Rev. No. 0

Job No. 22192 Checked $\frac{\text { ASE Date } 7 / 5 / 05}{\text { Sheet No. 10f1 }}$

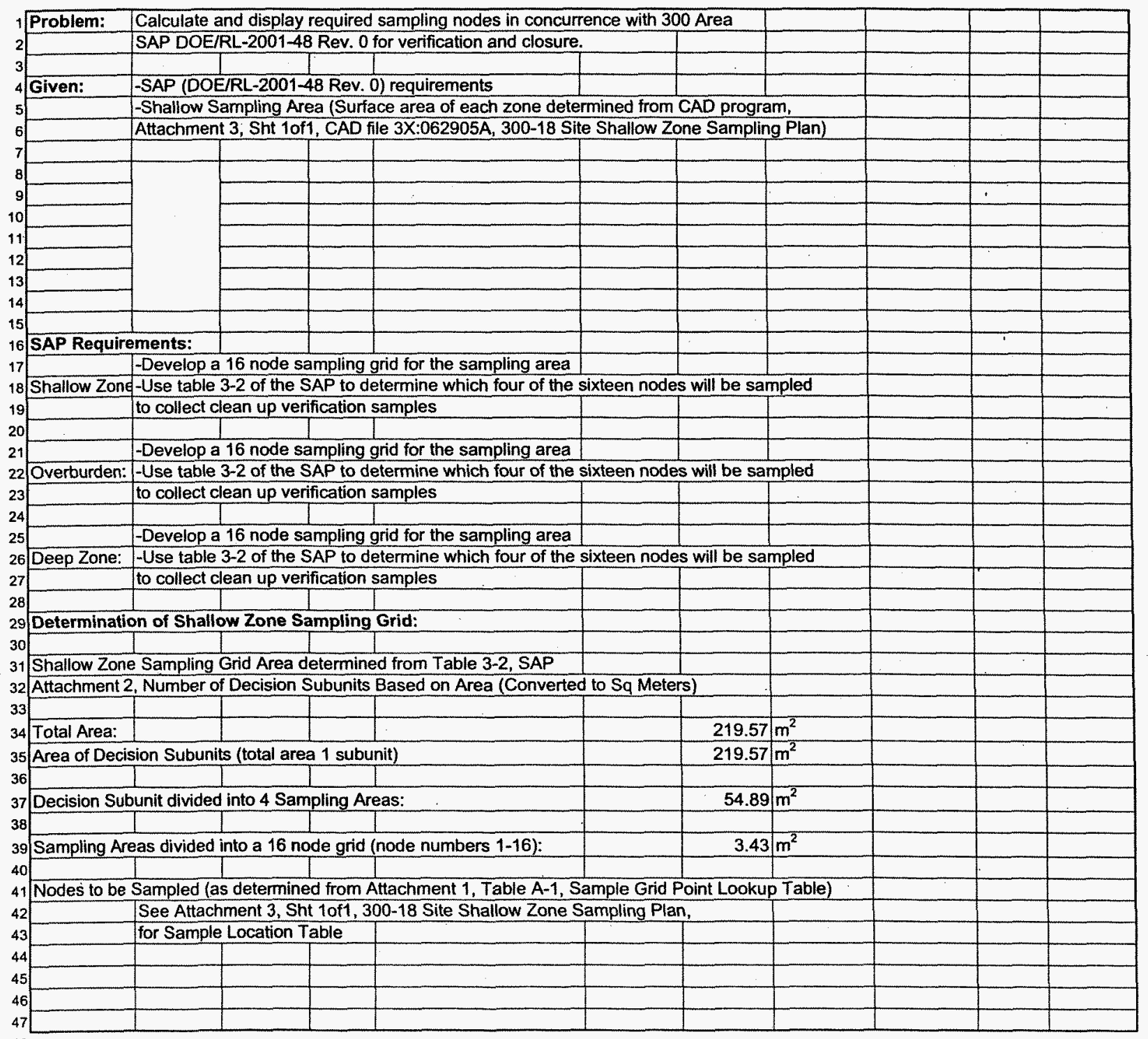


CVP-2005-00004

Rev. 0

Bechtel Hanford, Inc.

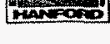

Originator G.Cruz Date 6/29/2005

Project

300-18 Site Sample Design

Calc. No.0300X-CA-V0054 Rev. No.0

Subject 300-18 Site Shallow Zone Sampling Plan

Job No. 22192 Checked CAB Date $7 / 5 / 65$ Sheet No 1 of1

\section{+ ATTACHMENT 1}

2

${ }_{3}$ Sample Grid Point Lookup Table.

4

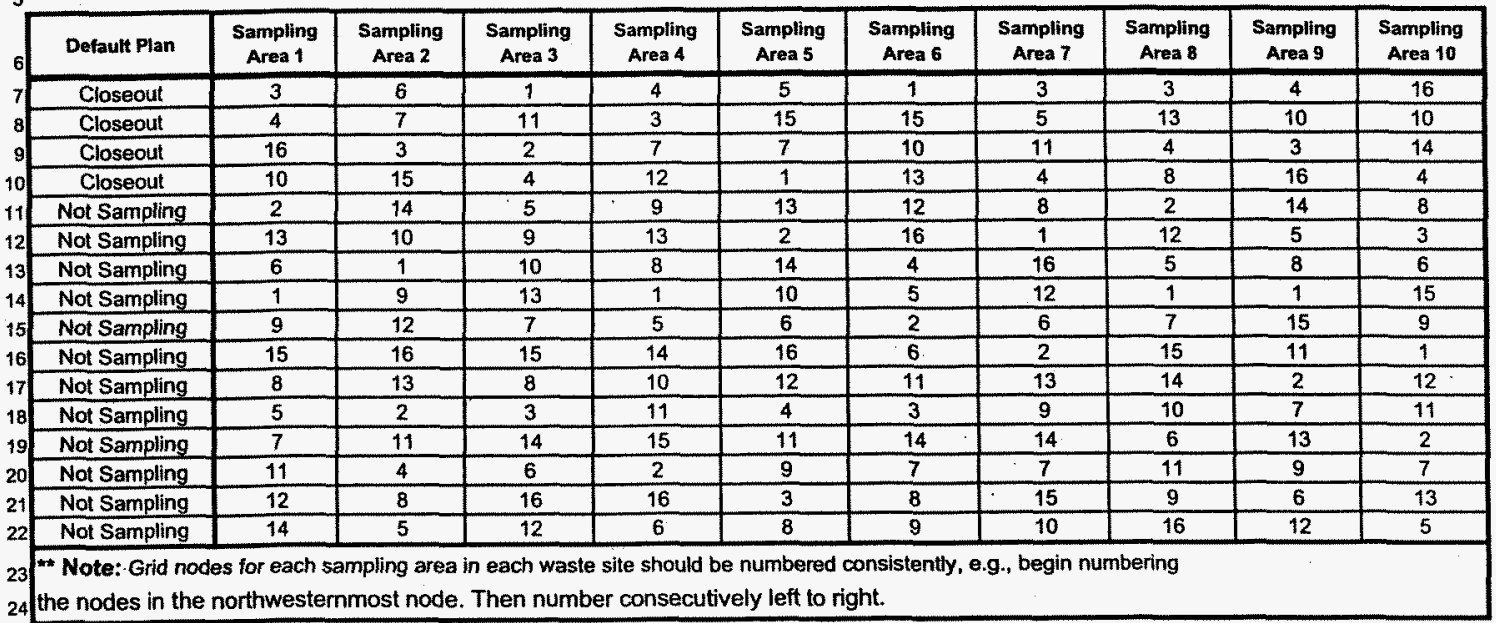

24 the nodes in the northwesternmost node. Then number consecutively left to right. 


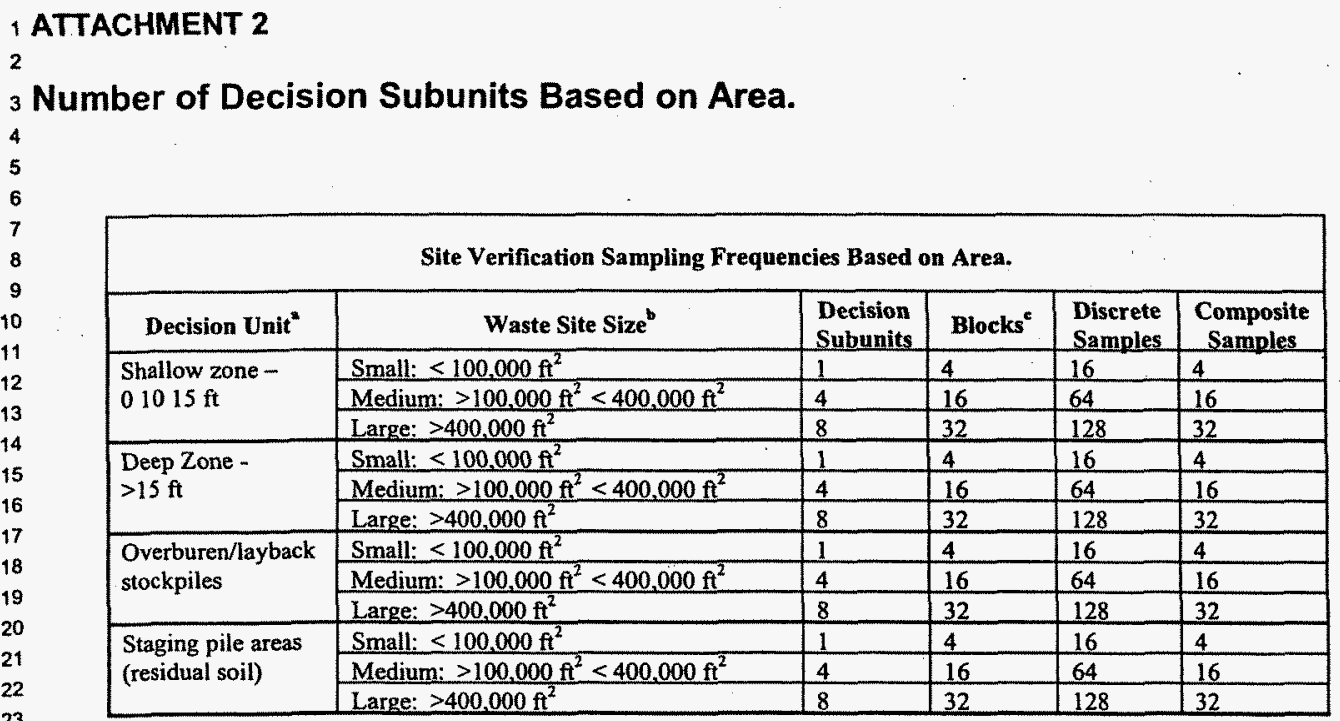

- The shallow zone, deep zone, overburden stockpile, and staging pile areas each represent single decision units. The total number of decision

units will vary because individual waste sites may not have a deep zone, overburden stockpile, and/or staging pile areas.

- Area of exposed surface after excavation or area of stockpile base (as applicable)

- Decision subunits are divided into four blocks to ensure that random sampling locations are not bunched together in one arca 


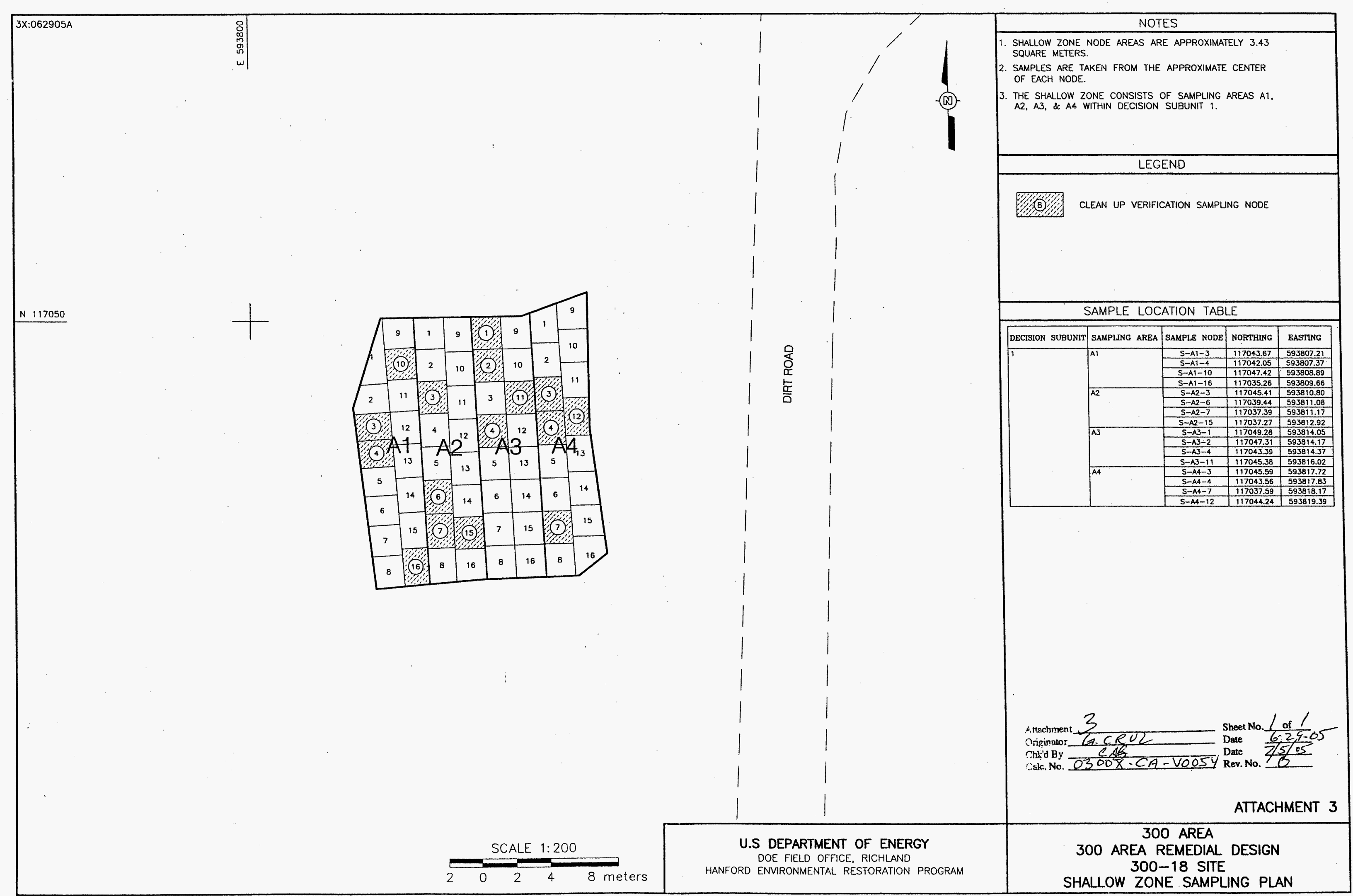




\section{CALCULATION COVER SHEET}

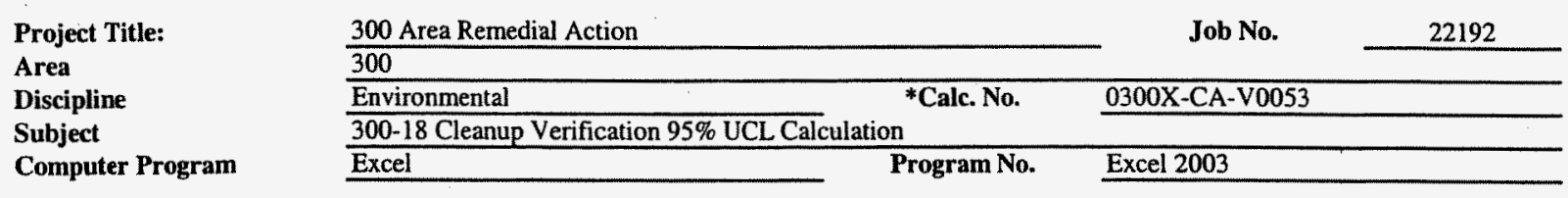

The attached calculations have been generated to document compliance with established cleanup levels. These documents should be used in conjunction with other relevant documents in the administrative record.

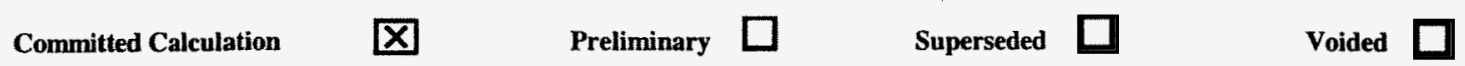

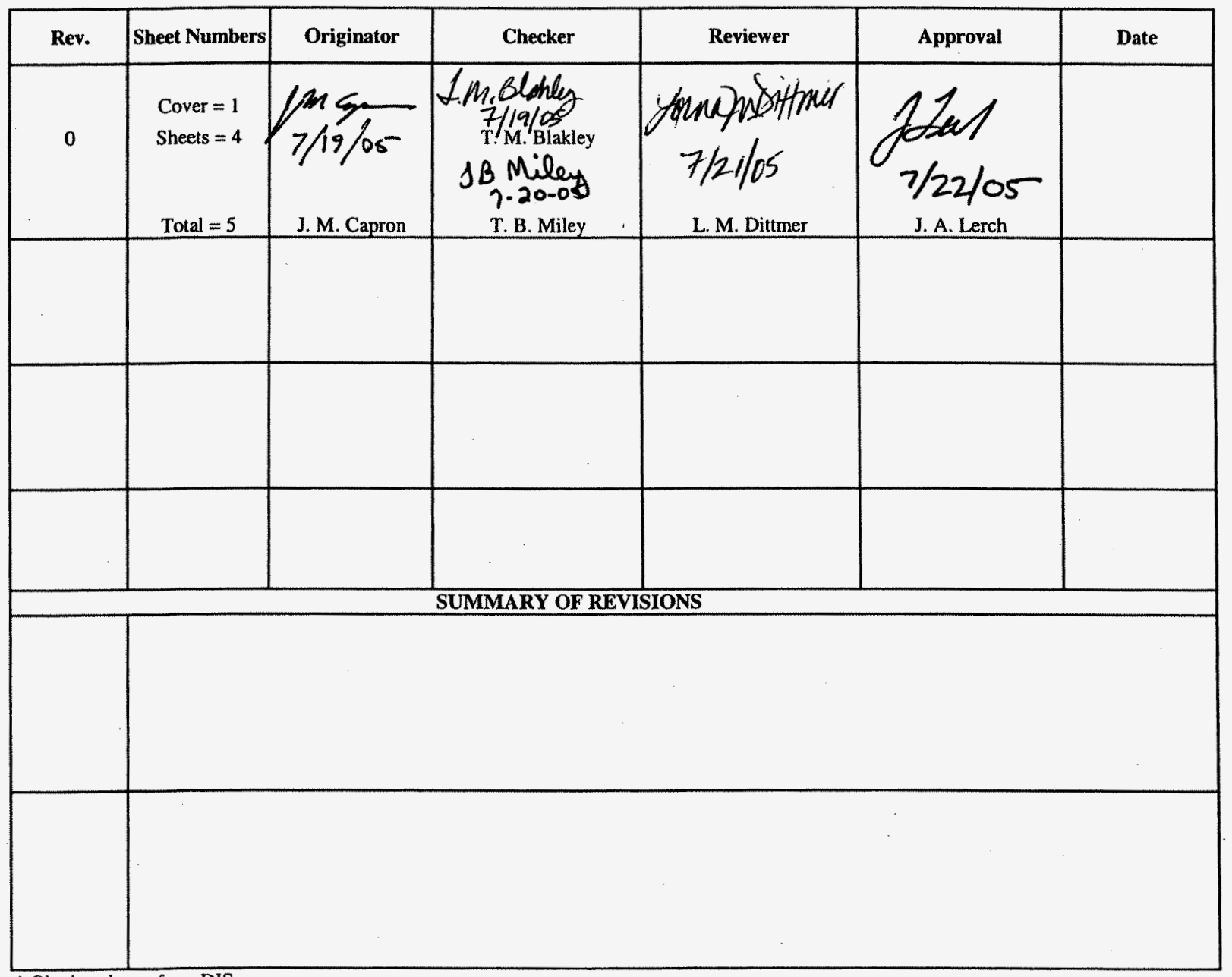

* Obtain calc no. from DIS

DE01437.03 (12/09/2004) 

Originator J. M. Capron Subject $300-18$ Cleanup Verification $95 \%$ UCL Calculation
Date 07/19/05 Job No. 22192
Calc. No. 0300X-CA-V0053 Checked T.M. Blakiex /20 B $7 / 19$

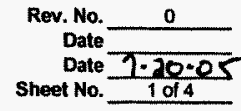

\section{Purpose:}

Calculate the $95 \%$ upper confidence limit (UCL) to evaluate compliance with cleanup standards for the subject site. Also, calculate the carcinogenic risk for applicable nonradionuclide analytes. perform the Washington Administrative Code (WAC) $173-340$ (Model Toxics Control Act (MTCA]) 3-part test (all nonradionuclide analytes), and calculate the relative percent difference (RPD) for each contaminant of concern (COC)

Table of Contents:

Sheets 1 to 2 - Calculation Sheet Summary

Sheet 3 - Calculation Sheet Shallow Zone

Sheet 4 - Calculation Sheet Split-Duplicate Analysis

1

Given/References:

1) Sample Results

14 All lookup values and remedial action goals (RAGs) are taken from the Remedial Design Report/Remedial Action Work Plan (RDRJRAWP) (DOE-RL 2004b) and Ecology (1996) unless otherwise specifed.

3) Background value for cadmium is from Natural Background Soil Metals Concentration in Washington State, Publication 94-115, Washington Department of Ecology, Olympia, Washington

4) Background values for all other analytes are from Hanford Site Background: Part 1. Soil Background for Nonradioactive Analytes, DOE/RL-92-24, Rev. 4, U.S. Department of Energy, Richland Operations Office, Richlafd, Washington.

5) DOE-RL 2004a, 300 Area Remedial Action Sampling and Analysis Plan, DOEJRL-2001-48, Rev, 1, U.S. Department of Energy, Richland Operations Office, Richtand, Washington.

6) DOE-RL, 2004b, Remedial Design ReportRemedial Action Work Plan for the 300 Area, DOE/RL-2001-47, Rev. 1, U.S. Department of Energy, Richtand Operations Office, Richland,

Washington.

7) Ecology, 1992, Statistical Guidance for Ecology Site Managers, Publication \$92-54, Washington State Department of Ecology, Olympia, Washington

8) Ecology. 1993, Statistical Guidance for Ecology Site Managers, Supplement S-6, Analyzing Site or Background Data with Below-Detection Limit or Below-PQL Values (Censored Data Sets) Publication \#92-54, Washington State Department of Ecology, Olympia, Washington.

9) Ecology, 1996, Model Toxics Control Act Cleanup Levels and Risk Calculations (CLARC II), Publication \#94-145, Washington State Department of Ecology, Otympia, Washington.

10) EPA, 1994, USEPA Contract Laboratory Program National Functional Guidelines for Inorganic Data Review, EPA 540/R-94/013, U.S. Environmental Protection Agency, Washington, D.C.

11) WAC 173-340, 1996, "Model Toxics Control Act-Cleanup." Washington Administrative Code.

Solution:

Calculation methodology is described in Ecology Pub. \#92-54 (Ecology 1992, 1993), below, and in the RDRIRAWP (DOE-RL. 2004b). Use data from attached worksheets to calculate the 95\% UCL, carcinogenic risk, and the RPD for each analyte and to perform the WAC 173-340 3-part test for nonradionuclides.

Calcutation Description:

The subject calculations were performed on data from soil verification samples from waste site 300-18. The data were entered into an EXCEL 2003 spreadsheet and cakculations performed by utilizing the buallin spreadsheet functions andlor creating formulae whthin the cells. The statistical evaluation of data for use in accordance with the RDR/RAWP (DOE-RL 2004b) is documented by this Calculation. Split and duplicate Mothodology:

The statistical value calculated to evaluate the effectiveness of cleanup was the $95 \%$ UCL. For nonradicactive analytes with > 50\% of the data beiow detection limits, the maximum value for the sample data was used instead of the $95 \%$ UCL. All nonradionuctide data reponted as being betow detection fimits were set to $1 / 2$ the detection limit value for calculation of the statistics (Ecology 1983). For radionuclide data, calculation of the statistics was done on the reported value. In cases whera the laboralory does not report a value below the minimal delectabie activity (MDA), half of the MDA is used in the calculation.

For the statistical evaluation of duplicate sample pairs, the samples are averaged before being included in the data set, atter acjustments for censored data as described above.

For nonradionuclides, the WAC $173-340$ statistical guidance suggests that a test for distributional form be performed on the data, and the 95\% UCL. calculated on the appropriate distribution using Ecology software. For nonradionuctide small data sets $(n<10$ ) and all radionuclide data sets, the calculations are performed assuming nonparametric distribution, so no lest for distribution is periornet. White not applicable to the $300-$ 18 site, for nonradionuclide data sets of ten or greater, distributional testing is done using Ecology's MTCAStat software (Ecology 1993).

The estimated hazard quotient (for applicable nonradionudide COCs) is detemined by dividing the statistical value (derived in this calculation) by the WAC $173-340$ non-carcincgenic cleanup limit The nonradionuclide carcinogenic risk, above background, is determined by dividing the statistical value by the WAC $173-340$ carcinogenic cleanup limil and then multiplying by $10^{-5}$. For data sets where all values are below detection, neither of these calculations are required.

The WAC 173-340 3-part lest is perfomed for nonradionuclide analytes only and determines it:

1) the statistical value exceeds the most stringent cleanup limit for each non-radionuclida $\mathrm{COC}$. 3) (10

The RPD is calculated when both the main value and either the duplicate or split values are above detection limits and are greater than 5 times the target detection timit (TDL). The TOL is a booratory detection limit pre-detemined for each analytical method. These detection limit requirements are listed in Tabte 2-1 of the sampling and anaysis plan (DOE-RL 2004a). The RPD calculations use the following lormula: RPD = $[$ IMSIR(M+SY2)]" 100

$$
\text { Where, } M=\text { Main Sample Value } \quad \mathbf{S}=\mathbf{S p l i l} \text { (or duplicate) Sample Value }
$$

For quality assurance/quality control (OAOC) split and duplicate RPD calculations, a value less than $+1.30 \%$ indicates the data compare favorably. For regulatory splits, a threshoid of +1 - 35\% is used (EPA 1994). If the RPD is greater than $+1-30 \%$ (or $+1-35 \%$ for regulatory spli data), further investigation regarding the usability of the data is performed. Additional discussion as necessary is provided in the data quality assessment section of the applicable CVP.

If regulator split comparison is required, an additional parameter is evaluated. A control fimit of $+1-2$ times the TDL shall be used if either the main or regulator split value is less than 5 times the TDL and above detection. In the case where cnly one resull is greater than 5 times the TDL and the other is below, the $+1-2$ times the rDL. criteria applies. Therefore, the following calculation is pertormed as part of the evaluation tor these wo cases involving regulator split data: difference = main - regulator split

If the difference is greater than $+1-2$ times the TOL, then further investigation regarding the usability of the data is performed and presented in the applicable CVP data quality assessment section.

No regulatory split samples were collected for the $300-18$ site. 
CVP-2005-00004

Rev. 0

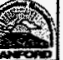

Bechtel Hantord. Inc.

Originator J.M. Capron 4 anc

Subject 300-18 Cleanup Verification $95 \%$ UCL Calculation

CALCULATION SHEET

Date 07/19/05 Job No. 22192

Summary (continued)

1 Results:

2 The results presented in the summary tables that follow are for use in RESRAD dose/risk analysis and the CVP for this site.

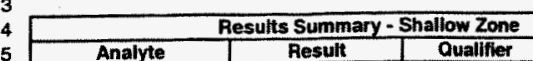

5 \begin{tabular}{|c|c|c|c|}
\hline Analyte & Resuit & Qualifier & Units \\
\hline Arsenic & $22 E+00$ & &
\end{tabular}

6 Arsenic

Barium

Beryllium

Cadmium

10 Chrom

Uranium (Total)

Uranium (Total $3.4 E+00$

AC 173-340 Evaluation (Shallow Zone)

3-Part Test:

$95 \%$ UCL $>$ Cleanup Limit?

$>10 \%$ above Cleanup Limit?

Any sample $>2 \times$ Cleanup Limir?

Risk Estimate:

Nonrad roncarcinogenic index sum:

Nonrad carcinogenic risk:

Calc. No. 0300X-CA-V0053

Checked T.M. Blakley /mB $\uparrow / 19705$

Cheeked T. B. Miley TBM
Aev. No.

Date

Date 7.20 .05

DPO

Results (Shallow Zone)* OAOC Analysis

\begin{tabular}{|c|c|c|}
\hline Analyte & $\begin{array}{c}\text { Duplicate } \\
\text { Analysis }\end{array}$ & Split Analysis \\
\hline
\end{tabular}

27 Arsenic

28 Barium

9 Beryilium

30 Cadinium

31 Chromium

32 Lead

34 "A biank cell indical

$35 \quad \mathrm{BG}=$ background

$36 \mathrm{CVP}=$ cleanup verfication pacikage

$37 \quad$ QAOC $=$ quality assurance/quality contro

38 RESRAD = RESiduat RADioactivity (dose model)

39 UCL $=$ upper confidence limit

$40 \mathrm{WAC}=$ Washington Administrative Code 
Rev. No. 0

Subject $300-18$ Cleanup Verification $95 \%$ UCL Calculation

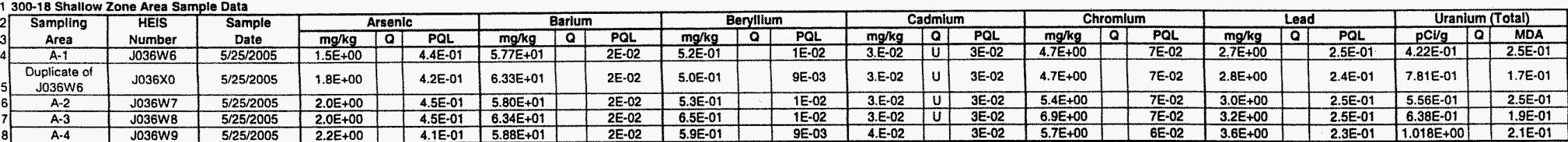

\begin{tabular}{|c|c|c|c|c|c|c|c|c|c|c|c|}
\hline \multirow[t]{3}{*}{10} & \multirow{2}{*}{$\begin{array}{c}\text { Sampling } \\
\text { Area }\end{array}$} & \multirow{2}{*}{$\begin{array}{l}\text { HEIS } \\
\text { Number } \\
\text { Jo36W6/ } \\
\text { J036X0 }\end{array}$} & \multirow{2}{*}{$\begin{array}{c}\text { Sample } \\
\text { Date }\end{array}$} & $\begin{array}{l}\text { Arsenic } \\
\mathrm{mg} / \mathrm{kg}\end{array}$ & $\begin{array}{l}\text { Bartum } \\
\mathrm{mg} / \mathrm{kg}\end{array}$ & \multicolumn{2}{|l|}{$\begin{array}{c}\text { Beryllium } \\
\text { mg/kg }\end{array}$} & $\begin{array}{c}\text { Cadmium } \\
\text { mg/kg }\end{array}$ & $\begin{array}{c}\text { Chromium } \\
\mathrm{mg} / \mathrm{kg}\end{array}$ & $\begin{array}{l}\text { Lead } \\
\text { mg/kg }\end{array}$ & 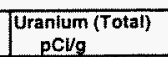 \\
\hline & & & & & $605 E+01$ & 5.tE-01 & & 2.E.02 & $4.7 E+00$ & $2.8 \mathrm{E}+00$ & $E=01$ \\
\hline & $A-2$ & $\frac{1030 \% W}{\text { Jo36 }}$ & $5 / 25 / 2005$ & $2.0 E+00$ & $5.80 E+01$ & $5.3 \mathrm{E} \cdot 01$ & 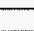 & $2 . E-02$ & $5.4 E+00$ & $3.0 \mathrm{E}+00$ & $5.56 E-01$ \\
\hline 14 & $A-3$ & Jo36W & $5 / 25 / 2005$ & $2.0 E+00$ & $6.34 E+01$ & $6.5 \mathrm{E}-01$ & 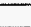 & 2.E. 02 & $6.9 E+00$ & $3.2 \mathrm{E}+00$ & $6.38 E-01$ \\
\hline & A.4 & J036W9 & $5 / 25 / 2005$ & $\frac{2.0 E+10}{2.2 E+00}$ & $5.88 E+01$ & $5.9 \mathrm{E}-01$ & & $4 . E-02$ & $5.7 \mathrm{E}+00$ & $3.6 \mathrm{E}+00$ & $1.018 E+00$ \\
\hline
\end{tabular}

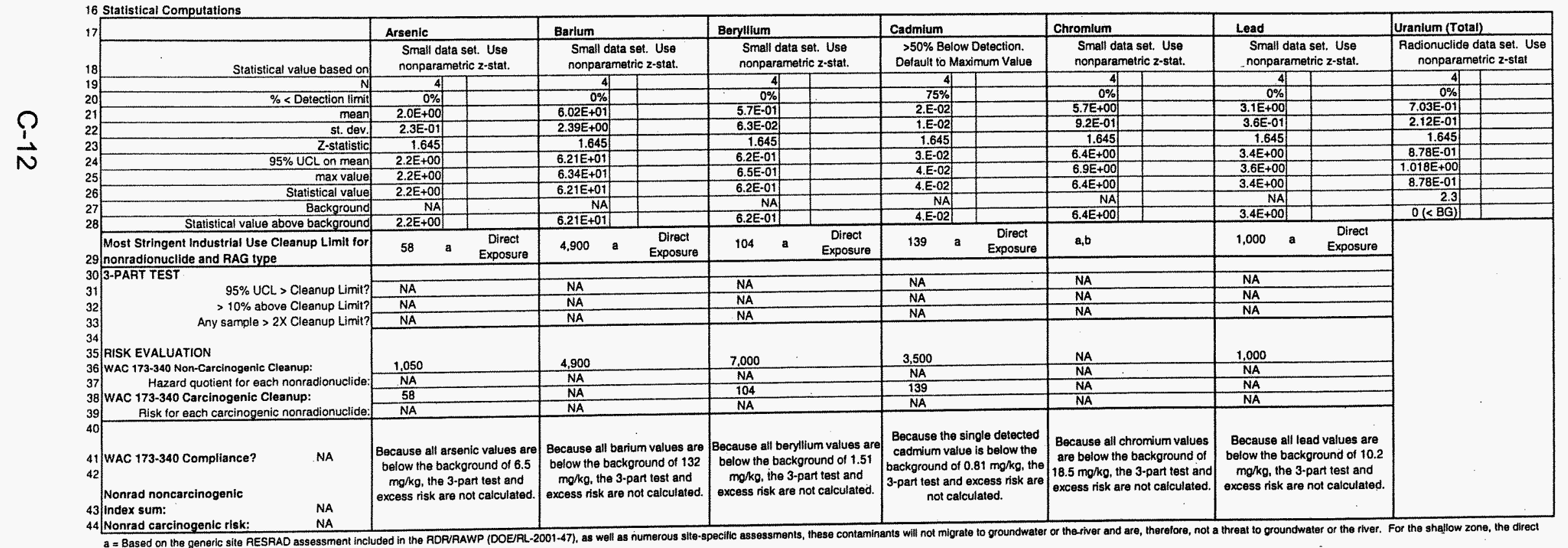

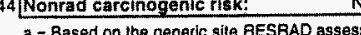

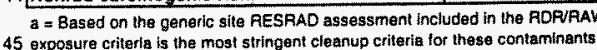

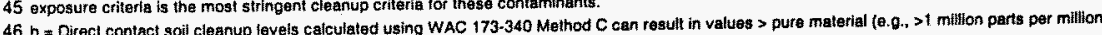

$47 \mathrm{BG}=$ background

48 HES = Hantord Environmental Intormation Syston

49 MOA = minimum delectabte activity

FAG $=$ reme

FAG = rembdia action poal

S1 POL = practical quantitation imi

$U=$ undatected 
CALCULATION SHEET

\section{Bechtel Hanford, inc}

Originator J.M. Capron $\ln \mathrm{K}$

Project 300-18 Burialaround

Subject 300-18 Cleanup Verification $95 \%$ UCL Calculation

Split/Duplicate Analysis:

\begin{tabular}{|c|c|c|c|c|c|c|c|c|c|c|c|c|c|c|c|c|c|}
\hline \multirow{2}{*}{\begin{tabular}{|c|c|}
2 & Composite \\
3 & Area
\end{tabular}} & \multirow[b]{2}{*}{ HEIS Number } & \multicolumn{2}{|c|}{ Arsenic } & \multicolumn{2}{|c|}{ Barium } & \multicolumn{3}{|c|}{ Beryllium } & \multicolumn{3}{|c|}{ Cadmium } & \multicolumn{2}{|c|}{ Chromlum } & \multicolumn{2}{|c|}{ Lead } & \multicolumn{2}{|c|}{ Uranium (Total) } \\
\hline & & $\mathrm{mg} / \mathrm{kg}$ & $\overline{\mathrm{PQL}}$ & $\mathrm{mg} / \mathrm{kg}$ & PQL & $\mathrm{mg} / \mathrm{kg}$ & वा & PQL & $\mathrm{mg} / \mathrm{kg}$ & a & PQL & $\mathrm{mg} / \mathrm{kg}$ & POL & $\mathrm{mg} / \mathrm{kg}$ & PQL & $\mathrm{pCl/g}$ & MDA \\
\hline$A-1$ & J036W6 & $1.5 E+00$ & $4.4 \mathrm{E}-01$ & $5.77 \mathrm{E}+01$ & $2 . E-02$ & $5.2 E-01$ & & $1 . E-02$ & $3 . E-02$ & U & $3 . E-02$ & $4.7 E+\infty$ & 7.E-02 & $2.7 E+00$ & $2.5 \mathrm{E}-01$ & $4.22 \mathrm{E}-01$ & $2.5 \mathrm{E}-01$ \\
\hline $\begin{array}{l}\text { Duplicate of } \\
\text { Jo36W6 }\end{array}$ & J036X0 & $1.8 E+\infty 0$ & 4.2E-01 & $6.33 \mathrm{E}+01$ & 2.E-02 & $5.0 E-01$ & & $9 . E-03$ & 3.E-02 & $U$ & 3.E-02 & $4.7 E+00$ & 7.E-02 & $2.8 E+00$ & 2.4E-01 & 7.81E-01 & 1.7E-01 \\
\hline $\begin{array}{l}\text { Split of } \\
\text { jo36W6 }\end{array}$ & J036X1 & $2.2 E+00$ & $1.0 \mathrm{E}+00$ & $6.77 E+01 \mid$ & $2.06 E+01$ & $2.8 E-01$ & $\mathrm{~J}$ & $5.2 E-01$ & 5.2E-01 & $u$ & $5.2 E-01$ & $7.4 E+00$ & $1.0 E+00$ & $2.6 \mathrm{E}+00$ & $1.0 E+00$ & $1.38 E+00$ & $9.12 E-02$ \\
\hline
\end{tabular}

7 Shallow Zone Analysis:

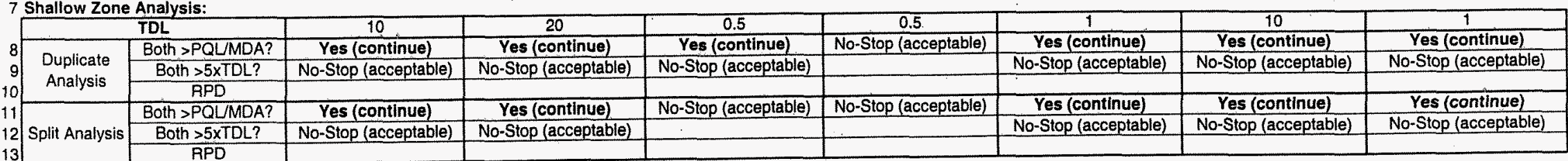

Date 07/19/05

Job No. 22192
Calc. No. 0300X-CA-V0053

Checked T.M. Blakley $7 \mathrm{mB} 7 / 19 / 05$

Checked TB.Miley $1 B M$
Rev. No. 0

Date $\overline{1-20-05}$

Sheet No. 4 of 4

\section{HEIS = Hantord Environmental Information System}

\section{$15 \mathrm{~J}=$ estimated}

$\vec{\omega} \quad 16 \mathrm{MDA}=$ minimum detectable activity

$17 \mathrm{PQL}=$ practical quantitation limit

$18 Q=$ qualifier

$19 \mathrm{RPD}=$ relative percent difference

$20 \mathrm{TDL}=$ target detection limit

$21 \mathrm{U}=$ undetected 
CVP-2005-00004

Rev. 0

C-14 


\section{DISTRIBUTION}

U.S. Department of Energy

$\underline{\text { Richland Operations Office }}$

D. C. Smith (5) A3-04

DOE-RL Public Reading Room H2-53

Fluor Hanford, Inc.

J. P. Shearer (WIDS)

A0-21

ERC Team

K. A. Anselm, $\mathrm{CHI}(2) \quad \mathrm{H9}-02$

J. M. Capron, BHI

$\mathrm{H} 9-01$

R. A. Carlson, BHI

$\mathrm{X} 0-17$

S. W. Clark, $\mathrm{CHI}$

$\mathrm{H} 9-01$

J. W. Darby, BHI

L6-06

L. A. Dietz, BHI

$\mathrm{HO}-23$

L. M. Dittmer, BHI

H9-02

J. A. Lerch, $\mathrm{CHI}$

L6-06

J. E. Thomson, $\mathrm{CHI}$

$\mathrm{HO}-23$

Document and Information Services (2) H0-30

Hanford Technical Library $\quad$ P8-55 
CVP-2005-00004

Rev. 0

Distr-2 